\title{
Procjenjivanje veličine neopažene ekonomije u Hrvatskoj korištenjem MIMIC pristupa
}

Klarić, Vjekoslav

Source / Izvornik: Odabrani prijevodi, 2011, 2, 1 - 31

Journal article, Published version

Rad u časopisu, Objavljena verzija rada (izdavačev PDF)

https://doi.org/10.3326/op.9

Permanent link / Trajna poveznica: https://urn.nsk.hr/urn:nbn:hr:242:642647

Rights / Prava: Attribution-NonCommercial-NoDerivatives 4.0 International/ImenovanjeNekomercijalno-Bez prerada 4.0 međunarodna

Download date / Datum preuzimanja: 2023-04-26

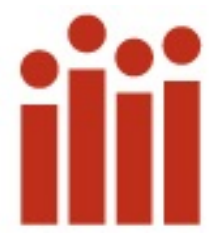

Institute of Public Finance Repository

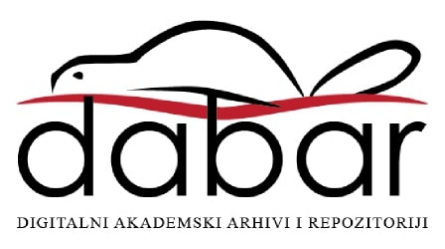




\section{ProcjenjIVANJE VeličIne NeOPAŽEne EKONOMIJE U HRVATSKOJ KORIŠTENJEM MIMIC PRISTUPA}

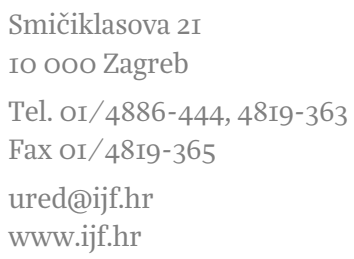

\section{ODABRANI PRIJEVODI}

\author{
ISSN I847-7445
}

\section{BR. 9/II}

citirati: Klaric, V., 20II. "Estimating the size of non-observed economy in Croatia using the MIMIC approach". Financial Theory and Practice, 35 (I), 59-90.

http://www.ijf.hr/eng/FTP/2OII/I/ klaric.pdf

Svi Odabrani prijevodi dostupni su na: http:/ /www.ijf.hr/index.php?ime=268

\author{
Vjekoslav KLARIĆ ${ }^{*}$ \\ vjekoslav_klaric@yahoo.com
}

\section{Sažetak}

Ovaj rad donosi kratak pregled pristupa koji su korišteni u istraživanju sive ekonomije. Navodi se nekoliko definicija pojmova 'siva ekonomija' i 'neopažena ekonomija', s posebnim osvrtom na okvire ISTAT-a i Eurostata, a nakon toga i nekoliko metoda za procjenjivanje veličine sive ekonomije i neopažene ekonomije. Naglasak se stavlja na MIMIC, jednu od metoda za procjenjivanje veličine neopažene ekonomije. Nakon kratkog prikaza teorije u pozadini MIMIC modela, isti je potom primijenjen na hrvatsko gospodarstvo. Uzevši u obzir svojstva pojedinih metoda, ranija procjena veličine neopažene ekonomije u Hrvatskoj izabrana je za izvor referentnih vrijednosti za MIMIC model. Koristeći te vrijednosti, dobivena je procjena veličine neopažene ekonomije u Hrvatskoj za period od 1998. do 2009. godine.

Ključne riječi: neopažena ekonomija, siva ekonomija, Hrvatska, MIMIC 


\section{Uvod}

Svatko tko je ikad pokušao primijeniti matematički model u stvarnom životu zna kako matematički modeli funkcioniraju idealno i bez poteškoća samo na papiru. Svatko tko se bavio modelima u ekonomiji zna da je modeliranje ekonomskih pojava najčešće zahtjevnije od modeliranja prirodnih pojava. No, nikakvo prethodno iskustvo nije potrebno kako bi se naslutilo da bavljenje sivom ekonomijom predstavlja poseban izazov. Čak i bez poznavanja formalne definicije, već i sam izraz 'siva ekonomija' daje naslutiti da je riječ o djelatnostima koje su mutne, teško vidljive. Dok su neke od njih nevidljive greškom, većina djelatnosti koje pripadaju sivoj ekonomiji stvorena je sa željom da bude skrivena. Ono što se ne može vidjeti teško je i opisati, a kamoli mjeriti. Usprkos tome, predstojeći je zadatak pokušati učiniti oboje.

Za prvi dio zadatka, izbor definicije sive ekonomije, moglo bi se reći da je proizvoljan, stvar osobnog ukusa, budući da ne postoji jedinstvena, univerzalno prihvaćena definicija. Kako bi se to pokazalo, na početku rada navedene su razne definicije, ali kako bi se osigurala konzistentnost rada, može se prihvatiti samo jedna. To će biti učinjeno u drugom poglavlju rada, dok će treće poglavlje dati kratak pregled metoda koje su korištene za mjerenje hrvatske neopažene ekonomije.

Za drugi dio zadatka bit će korišten MIMIC pristup. Jedan od ciljeva ovog rada je predstaviti MIMIC model, njegova svojstva i teoriju na kojoj počiva. Nalaženje ispravnog načina primjene modela, kao i prikupljanje podataka za unos u model, predstavlja dodatni izazov. Naposljetku, nakon obrade podataka odgovarajućim softverom, izlazne vrijednosti modela moraju biti pažljivo obrađene i interpretirane, i matematički i ekonomski. Time bi se trebao postići primarni cilj ovog rada, iskorištenje MIMIC modela u svrhu procjenjivanja veličine neopažene ekonomije u Hrvatskoj, učinaka koje je na nju imao početak recesije i njene povezanosti s drugim ekonomskim varijablama. Iako bi ti učinci trebali biti predvidivi, njihov opseg nije. MIMIC će općenito biti opisan u 4. poglavlju rada, dok će se 5. poglavlje baviti primjenom MIMIC-a na hrvatsko gospodarstvo. Izbor varijabli i proces prilagodbe bit ce detaljno objašnjeni $u$ dodacima. Posljednji dodatak ispitat ce postupke korištene $u$ istraživanju $u$ svjetlu Breuschevih (2005) primjedbi.

Bit će zanimljivo vidjeti je li blago kontroverzni MIMIC pristup uopće primjenjiv na gospodarstvo poput hrvatskog i s kojim se izazovima istraživač suočava na takvom projektu. Ako se pokaže mogućim, i samo dobivanje procjene hrvatske neopažene ekonomije bi trebalo biti zanimljivo, budući da je za ovo razdoblje dostupan mali broj procjena.

\section{2. Što su siva ekonomija i neopažena ekonomija}

\section{I. Kako definirati sivu ekonomiju}

Kroz povijest istraživanja sive ekonomije, različiti znanstvenici koristili su različite definicije tog pojma. Neke od njih bile su kratke i sažete, dok su druge bile složenije i bolje razrađene. Na primjer, Schneider i Enste (2000) definiraju sivu ekonomiju kao skup ekonomskih aktivnosti koje doprinose službenom bruto domaćem proizvodu, ali nisu registrirane. 
Feige (1979) je jednostavno definirao sivu ekonomiju kao skup ekonomskih aktivnosti koje su neprijavljene ili nisu izmjerene. No kasnije, isti autor (Feige, 1990) daje kudikamo kompliciraniju definiciju. Navodi da se sve ekonomske aktivnosti mogu podijeliti u dvije skupine: na one koje su sukladne postojećim institucionalnim pravilima i na one koje to nisu. Potonje aktivnosti pripadaju sivoj ekonomiji i dalje se dijele na nezakonitu, neprijavljenu, nezabilježenu i neformalnu ekonomiju. Aktivnosti koje pripadaju nezakonitoj ekonomiji kose se sa zakonima, aktivnosti koje pripadaju neprijavljenoj ekonomiji ostvaruju prihode koji nisu prijavljeni fiskalnim vlastima, one koje pripadaju nezabilježenoj ekonomiji nisu prijavljene nadležnim statističkim uredima, a one koje pripadaju neformalnoj ekonomiji zaobilaze troškove vezane uz regulativu, ali također ne mogu koristiti ni prednosti koje regulativa pruža.

Još jedan primjer „razgranate“ definicije dao je OECD (2002) u svom priručniku „Measuring the NonObserved Economy“. Pojam koji se primarno opisuje u priručniku je "Non-Observed Economy” (skraćeno: NOE) ili, u prilično grubom doslovnom prijevodu, neopažena ekonomija tj. neopaženo gospodarstvo. Analitički okvir za neopaženu ekonomiju, opisan u priručniku, djelo je talijanskog državnog instituta za statistiku (ISTAT). Prema njemu, NOE se dijeli na skrivenu, neformalnu i nezakonitu proizvodnju. Skrivena se proizvodnja zatim dijeli po razlozima nastajanja. Naposljetku, postoji sedam tipova NOE po ISTAT-u, označenih sa Ti - T7.

\section{Slika I.}

ISTAT-ov okvir za neopaženu ekonomiju (NOE) ${ }^{\text {I }}$

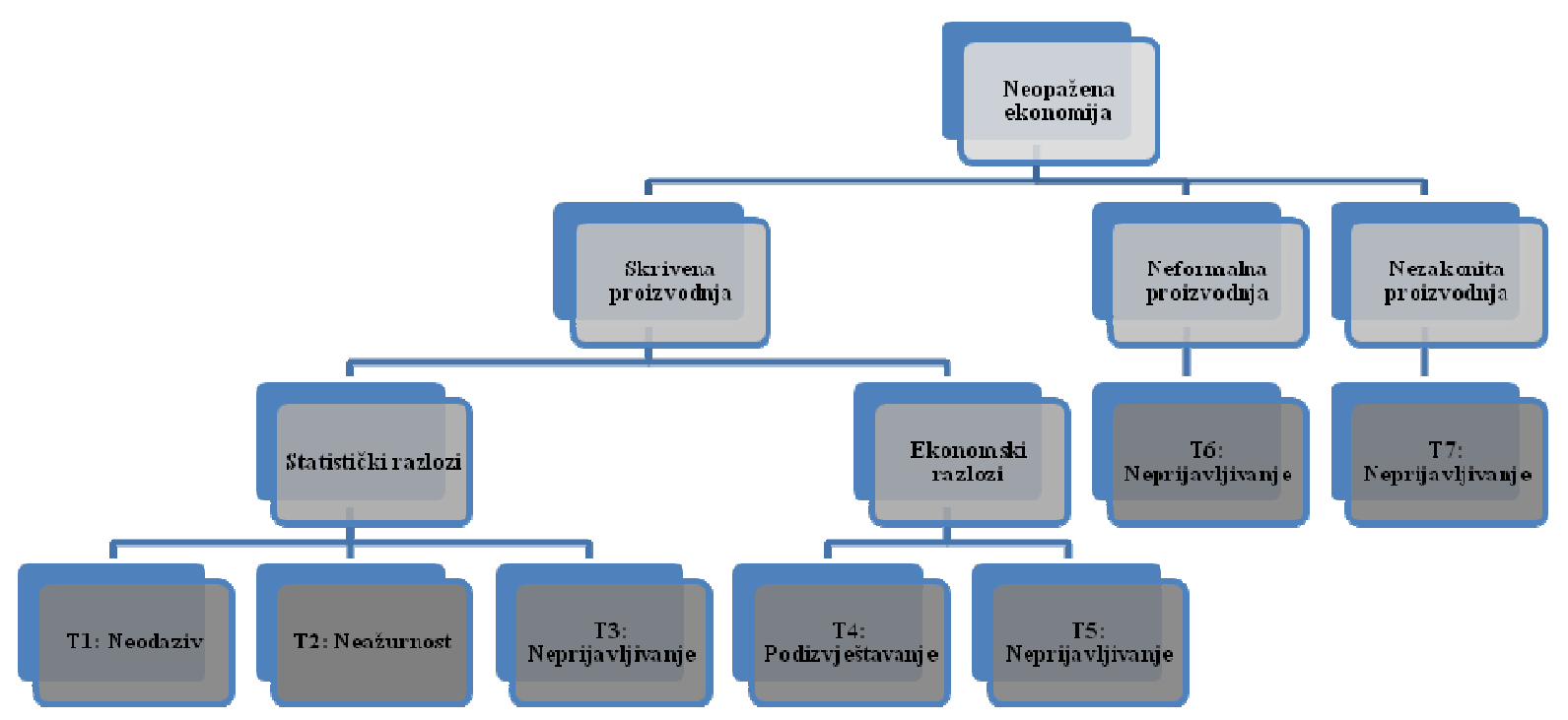

Izvor: OECD (2002).

${ }^{\text {I }}$ Moguće su i drugačije verzije grananja neopažene ekonomije, uslijed specifičnosti različitih nacionalnih ekonomija. 
Može se uočiti kako se izraz "siva ekonomija" ne pojavljuje izravno u ISTAT-ovom okviru. U užem smislu, taj izraz odnosi se na stavke $\mathrm{T}_{4}$, T5 i T6, tj. ekonomski dio neopažene ekonomije. S druge strane, veoma se često koristi u širem kontekstu, kao sinonim za neopaženu ekonomiju.

Eurostat (OECD, 2002) je osmislio modifikaciju ovog okvira i izvorno je namijenio zemljama kandidatkinjama za ulazak u Europsku uniju. Karakterizira je dodatan skup aktivnosti koje pripadaju neopaženoj ekonomiji (T8) i bolje razrađena klasifikacija.

T8 se sastoji od oblika neobuhvaćanja BDP-a koji nisu ranije navedeni. Tu se ubrajaju proizvodnja za vlastitu završnu uporabu, napojnice, nadnice i plaće u naturi, vrednovanje prilagodbi za neobuhvaćeni dio dohotka, porezi i subvencije na proizvode, pouzdanost "quantity-price" (količina-cijena) metoda i proizvodne bilance

\subsection{Eurostatova metoda procjene veličine neopažene ekonomije}

Jedna od metoda za procjenu veličine neopažene ekonomije temelji se na Eurostatovom (2002) okviru i stoga se naziva Eurostatova metoda. Riječ je zapravo o skupu metoda za procjenjivanje veličine svakog od tipova neopažene ekonomije prema Eurostatu. Ova metoda vjerojatno je jedna od najpodrobnijih, ako ne i najpodrobnija metoda za procjenu veličine neopažene ekonomije. Najpodrobnija znači i najsloženija, pa se ova metoda stoga rijetko koristi za davanje procjena za periode dulje od par godina.

Jedna od poteškoća koje se može pojaviti prilikom korištenja Eurostatove metode je to što svaka procjena donosi sa sobom stanovitu grešku, a kad se kombinira više metoda, također se kombinira više pogrešaka.

\section{Neke druge metode procjenjivanja veličine neopažene ekonomije}

Baš kao što definicije sive ili neopažene ekonomije uvelike variraju, tako variraju i metode procjene njene veličine. Slijedi nekoliko primjera metoda ranije primjenjivanih na hrvatsko gospodarstvo. Njihovi rezultati prikazani su na slici 5.

\section{I. Metoda sustava nacionalnih računa}

Metoda sustava nacionalnih računa (SNA) je još jedna metoda vezana uz posebnu definiciju i na neki je način preteča ISTAT-ovog/Eurostatovog pristupa. Sustav nacionalnih računa, objavljen 1993. godine, donosi statistički pogled na neopaženu ekonomiju i dijeli je na skrivenu i neformalnu proizvodnju te proizvodnju za vlastitu završnu uporabu. SNA metoda koristi neslaganje u nacionalnim računima kako bi procijenila veličinu neopažene ekonomije i počiva na osnovnom zakonu kružnog toka u ekonomiji. Taj zakon kaže da je rashod jednom subjektu u gospodarstvu prihod nekom drugom subjektu u istom gospodarstvu. NOE se mjeri kao razlika između službenog BDP-a mjerenog rashodnim i proizvodnim pristupom, tj. kao razlika između ukupne ponude i ukupne potražnje. 


\subsection{Monetarne metode}

Monetarne metode česte su metode za procjenu veličine neopažene ekonomije. Karakterizira ih jednostavnost prikupljanja podataka i izračuna, ali i jaki uvjeti koji su nužni kako bi metode funkcionirale. Primarna pretpostavka koja se koristi u većini monetarnih metoda, poput Gutmannove (1977) ili Tanzijeve (1983), je da je brzina opticaja novca u NOE jednaka brzini opticaja novca u službenom gospodarstvu, što je u najboljem slučaju kontroverzno.

Daljnji problemi javljaju se prilikom primjene ovih metoda na gospodarstva tranzicijskih zemalja. One jednostavno nisu načinjene tako da bi mogle uzeti u obzir neke od pojava koje se mogu javiti u tranzicijskim gospodarstvima, npr. hiperinflaciju, i stoga su nužne stanovite modifikacije prije no što se na njih primijene.

Pa ipak, monetarne metode značajno su evoluirale od svog prvog pojavljivanja i metode temeljene na Gutmannovom i Tanzijevom pristupu još se i dan danas koriste za procjenjivanje veličina neopaženih ekonomija diljem svijeta.

\subsection{Metoda potrošnje električne energije}

Metoda potrošnje električne energije je metoda procjene veličine neopažene ekonomije temeljena na pretpostavci da aktivnosti neopažene ekonomije, iako neprijavljene, svejedno moraju koristiti resurse, kao što je električna energija. Veličina NOE procijenjena je promatranjem veze između potrošnje električne energije i BDP-a.

Glavni izvor kritika bilo koje metode potrošnje električne energije dvojbena je stabilnost odnosa između potrošnje električne energije i BDP-a. Na taj odnos mogu vjerojatno utjecati mnogi vanjski čimbenici, kao npr. vremenski uvjeti. Na većinu metoda potrošnje električne energije, posebno na one koje koriste ukupnu potrošnju, također utječe proces tranzicije. Druge metode, poput pristupa baziranog na potrošnji električne energije u kućanstvima, kojeg je razvila Maria Lacko (1998), na koje tranzicija ne utječe $u$ tolikoj mjeri, znaju imati ograničen opseg. Tako je pristup baziran na potrošnji električne energije u kućanstvima ograničen na aktivnosti koje troše struju iz kućanstava.

\section{MIMIC model}

\section{I. O MIMIC-U}

Prilikom pokušaja analize i modeliranja neke varijable, vjerojatno prva stvar koja pada na pamet regresijska je analiza. Jasno je da je poznavanje načina na koji druge varijable utječu na predmet istraživanja veoma korisno. No taj postupak zahtjeva poznavanje ili procjenu određenog broja vrijednosti ne samo nezavisnih, nego i zavisne varijable. Kako je neopažena ekonomija neopaziva, regresija sama po sebi nije izvediva, bar ne bez da se prije postupka nađe način procjene veličine neopažene ekonomije. 
Primjena MIMIC-a na neopaženu ekonomiju privlačna je zato što se čini da taj model daje i procjenu veličine neopažene ekonomije i njenu vezu s drugim varijablama.

MIMIC (Multiple Indicators Multiple Causes) model pripada obitelji LISREL (Linear Independent Structural Relationship) modela, a za dobivanje podataka o predmetu istraživanja koristi modeliranje strukturalnim jednadžbama (SEM). Prvi put su ga predstavili Jöreskog i Goldbreger (1975), a njegovu suvremenu formu vjerojatno su najbolje opisali Giles i Tedds (2002).

MIMIC takoreći zaobilazi činjenicu da je predmet istraživanja neopaziva varijabla. Prvo se uvodi sustav jednadžbi poput onog u regresijskoj analizi:

$$
\eta_{\mathrm{t}}=\gamma^{\prime} \mathrm{x}_{\mathrm{t}}+\zeta_{\mathrm{t}}
$$

pri čemu je $x_{t}=\left\lfloor\begin{array}{lllll}x_{1 t} & x_{2 t} & . & . & x_{q t}\end{array}\right\rfloor ’\left(\begin{array}{lll}q & x & \text { I }\end{array}\right)$ vektor vremenskih nizova, od kojih je svaki potencijalni uzrok neopazivog vremenskog niza $\eta_{\mathrm{t}}, \gamma^{\prime}$ je (I x q) vektor koeficijenata koji opisuju vezu između $\mathrm{x}_{\mathrm{t}}$ i $\eta_{\mathrm{t}}$, a $\zeta_{\mathrm{t}}$ izraz koji označava pogrešku.

Model opisan jednadžbom (I) naziva se model strukturalnih jednadžbi i zapravo je regresijski model s neopazivom zavisnom varijablom. Iako se $\eta_{\mathrm{t}}$ ne može mjeriti izravno, pretpostavka je da ipak ima utjecaj na skup opazivih varijabli. Te se varijable zovu indikatori, a njihova veza $s \eta_{\mathrm{t}}$ opisana je mjernim modelom:

$$
\mathrm{y}_{\mathrm{t}}=\lambda \eta_{\mathrm{t}}+\varepsilon_{\mathrm{t}}
$$

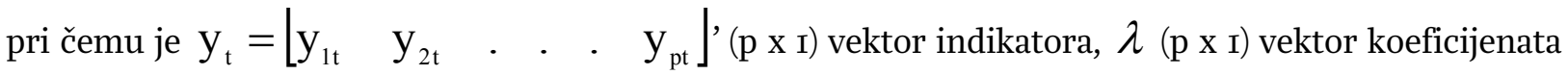
koji opisuju vezu između $\eta_{\mathrm{t}} \mathrm{i} \mathrm{y}_{\mathrm{t}}$, a $\varepsilon_{\mathrm{t}}$ pogreška I(o) vrste.

Pretpostavlja se da obje pogreške imaju očekivanje nula $\left(\mathrm{E}\left[\zeta_{\mathrm{t}}\right]=\mathrm{O}, \mathrm{E}\left[\varepsilon_{\mathrm{t}}\right]=\mathrm{o}\right)$, i da su međusobno nekorelirane.

Nadalje, neke od standardnih oznaka korištenih uz MIMIC su:

$\Sigma$ - kovarijantna matrica čitavog MIMIC modela

$\Phi$ - kovarijantna matrica od $\mathrm{x}_{\mathrm{t}}$

$\Psi-\operatorname{varijanca}$ od $\zeta_{\mathrm{t}}$

$\Theta=$ kovarijantna matrica od $\varepsilon_{\mathrm{t}}$.

Struktura modela može se prikazati idućim dijagramom. 


\section{Slika 2.}

Struktura MIMIC q-I-p modela

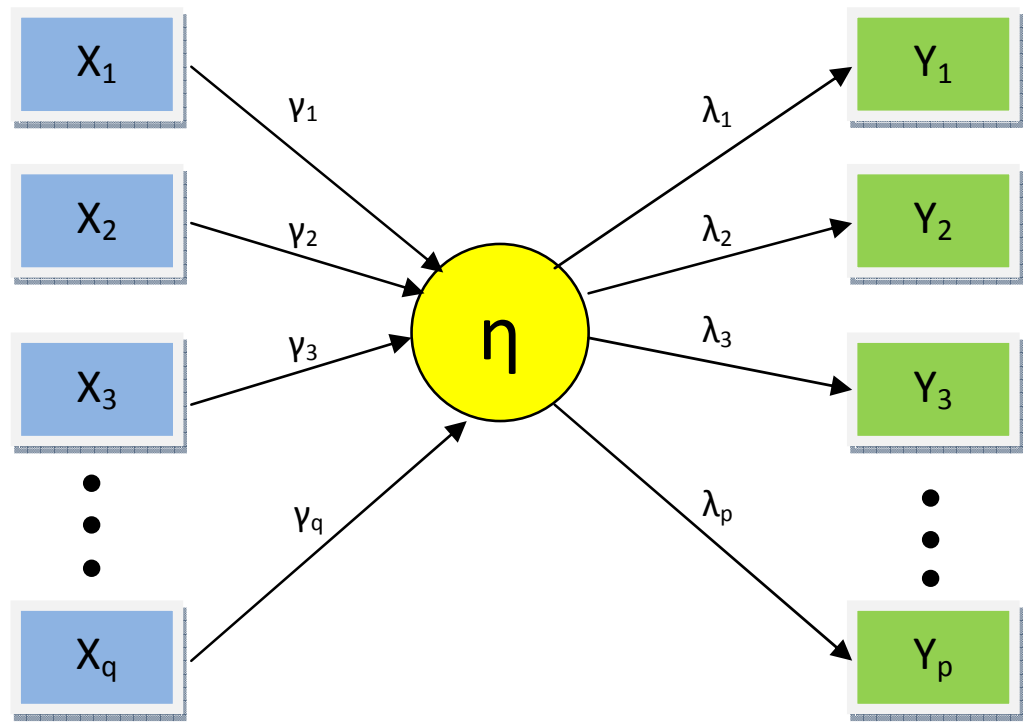

Izvor: Temeljeno na Gilesu i Tedds (2002).

Dakle, dva su skupa opazivih varijabli povezana preko neopazive:

$\eta_{\mathrm{t}}=\gamma^{\prime} \mathrm{x}_{\mathrm{t}}+\zeta_{\mathrm{t}}$

$\mathrm{y}_{\mathrm{t}}=\lambda \eta_{\mathrm{t}}+\varepsilon_{\mathrm{t}} \Rightarrow \lambda^{-1}\left(\mathrm{y}_{\mathrm{t}}-\varepsilon_{\mathrm{t}}\right)=\eta_{\mathrm{t}}$

$\lambda^{-1}\left(\mathrm{y}_{\mathrm{t}}-\varepsilon_{\mathrm{t}}\right)=\gamma^{\prime} \mathrm{x}_{\mathrm{t}}+\zeta_{\mathrm{t}}$

$\mathrm{y}_{\mathrm{t}}=\lambda \gamma^{\prime} \mathrm{x}_{\mathrm{t}}+\lambda \zeta_{\mathrm{t}}+\varepsilon_{\mathrm{t}}$

ili

$\mathrm{y}_{\mathrm{t}}=\Pi \mathrm{x}_{\mathrm{t}}+\mathrm{v}_{\mathrm{t}}$,

pri čemu je $\Pi=\lambda \gamma^{\prime}$ i $v_{t}=\lambda \zeta_{\mathrm{t}}+\varepsilon_{\mathrm{t}}$, iako skraćena forma može biti varljiva zbog svoje sličnosti s linearnom regresijskom jednadžbom. Problem je još jednom složeniji, jer postoji dodatni uvjet kojeg valja uzeti u obzir prilikom procjenjivanja parametara. Parametri trebaju biti procijenjeni tako da, označimo li redove od $\Pi$ sa $\mathrm{r}_{\mathrm{I}}, \ldots, \mathrm{r}_{\mathrm{p}}$, a stupce $\mathrm{sa}_{\mathrm{I}}, \ldots, \mathrm{c}_{\mathrm{q}}$, vrijedi:

$\Pi=\left[\begin{array}{c}r_{1} \\ r_{2} \\ \cdot \\ \cdot \\ \cdot \\ r_{p}\end{array}\right] \Rightarrow r_{i}=\lambda_{i} \lambda_{j}^{-1} r_{j}, \forall i, j=1, \ldots, p$ 


$$
\Pi=\left[\begin{array}{lllll}
\mathrm{c}_{1} & \mathrm{c}_{2} & . & . & \mathrm{c}_{\mathrm{q}}
\end{array}\right\rfloor \Rightarrow \mathrm{c}_{\mathrm{k}}=\gamma_{\mathrm{k}} \gamma_{1}^{-1} \mathrm{c}_{1}, \forall \mathrm{k}, 1=1, \ldots \mathrm{q}
$$

Rang matrice П mora biti I, budući da njeni reci i stupci očito moraju biti zavisni, zbog činjenice da je П umnožak (p x I) vektora i ( I x q) vektora:

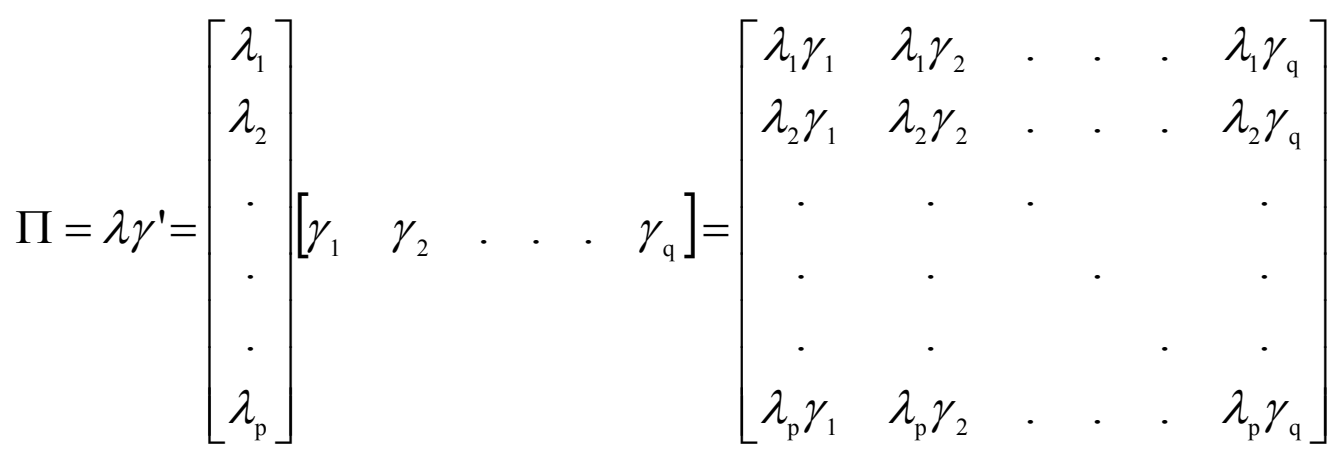

Čak i ako su vrijednosti od П poznate, još uvijek valja naći način kako razdvojiti $\gamma$ do $\lambda$.

Taj dio problema postaje prilično jednostavan kad se koristi konvencija koju su usvojili Giles i Tedds (2002). Budući da MIMIC model nije u stanju odrediti razinu svih parametara, potreban je uvjet normalizacije, a njihova je konvencija da prvi element od $\lambda$ bude jediničan: $\lambda_{\mathrm{I}}=\mathrm{I}$. U ovisnosti o tome kakav je pretpostavljeni odnos između $\eta_{\mathrm{t}}$ i $\mathrm{y}_{\mathrm{t}}, \lambda_{\mathrm{I}}$ se ponekad postavlja na $\lambda_{\mathrm{I}}=-\mathrm{I}$.

Prava procjena parametara u MIMIC modelu dobiva se koristeći kovarijantnu matricu modela. Ta matrica opisuje veze među opazivim varijablama preko njihovih kovarijanci i dana je s:

$\Sigma=\left[\begin{array}{cc}\Pi \Phi \gamma+\lambda \Psi+\Theta & \Pi \Phi \\ \Phi \Pi^{\prime} & \Phi\end{array}\right]$

Parametri su procijenjeni tako da razlike između $\Sigma$ i kovarijantne matrice uzorka budu što manje.

\section{I. Kritike MIMIC pristupa}

Jedan od najpoznatijih kritičara korištenja MIMIC modela u svrhu procjenjivanja neopažene ekonomije profesor je Trevor Breusch s Australskog nacionalnog sveučilišta. U svom radu naslovljenom "Estimating the Underground Economy using MIMIC models" (2005), on kritički preispituje čitav MIMIC pristup kao i njegove primjene od strane Gilesa i Tedds (2000), Bajade i Schneidera (2005), te Dell'Annoa i Schneidera (2003) kako bi prikazao česte pogreške i anomalije koje se mogu dogoditi prilikom korištenja MIMIC-a za procjenu veličine NOE.

Glavne zamjerke koje je Breusch iznio u vezi MIMIC pristupa i njegovih primjena su:

I) Nedokumentirane transformacije podataka, kao što su diferenciranje, transformiranje u razlike od očekivanja, skaliranje u svrhu dobivanja jedinične standardne devijacije... Primjena parametara procijenjenih koristeći transformirane podatke na netransfromirane varijable.

2) Osjetljivost na promjene jedinica mjere: mjerenjem varijabli u različitim jedinicama dobivaju se različiti rezultati. 
3) Diferenciranje varijabli kako bi se osigurala stacionarnost je nepotrebno, neučinkovito, stvara probleme i/ili rezultira procjeniteljem koji nije dugoročno povezan s endogenim varijablama koje bi trebao procijeniti.

4) Predznak jediničnog koeficijenta tijekom normalizacije ponekad je izabran samo iz pogodnosti ili tako da bi predznaci ostalih koeficijenata imali smisla. Zamjena predznaka jediničnog koeficijenta okreće kretanje rezultata naopako ako je latentna varijabla interpretirana kao niz promjena.

5) Proizvoljna prilagodba: korištenje zbrajanja kako bi se prilagodio rezultat, „klizanje“ čitavog grafa na određeni položaj.

6) Jedna kauzalna varijabla može dominirati latentnom varijablom i skoro isključivo pridonositi kretanju procijenjenog vremenskog niza.

7) Kretanje procjene NOE nema previše veze s aktivnostima NOE, nego s trendovima koji su prisutni u čitavoj ekonomiji i kod ekonomskih varijabli koje su s njom u vezi.

8) NOE nije latentna ili hipotetska veličina poput recimo inteligencije, što čini MIMIC slabije primjenjivim $\mathrm{u}$ ekonomiji, nego $\mathrm{u}$ psihometriji, iz koje potječe. Za razliku od psihometrijskog primjera $u$ kojem se mjerne jedinice mogu odrediti dogovorom, koncept $\mathrm{i}$ mjerenje prihoda $\mathrm{u}$ neopaženoj ekonomiji isti su kao u opaženoj.

9) Varijante službenog BDP-a i držanje novca ne mogu biti mjere istog neopazivog entiteta, ponajmanje NOE.

Postupci korišteni u primjeni MIMIC modela na hrvatsko gospodarstvo u idućem poglavlju ispitani su imajući ove kritike na umu u dodatku 4.

\section{Primjena MIMIC-a na hrvatsko gospodarstvo}

\section{I. Biranje uzroka i indikatora}

\section{I.I. Uzroci}

Prvo što valja učiniti kako bi se MIMIC model mogao primijeniti, izbor je varijabli i prikupljanje podataka. Poznato je kako je predmet istraživanja u ovom radu veličina neopažene ekonomije $u$ Hrvatskoj, pa valja načiniti popis potencijalnih uzroka i indikatora NOE. Iduće su kauzalne varijable korištene u ovom istraživanju:

Porezni teret vjerojatno je najčešće korištena varijabla kojom se objašnjava pojavljivanje neopažene ekonomije. Kod nekih pristupa porezi se navode i koriste čak kao jedini ili barem najvažniji razlog za bavljenje djelatnostima iz područja NOE.

Porezi utječu na troškove života kao i troškove poslovanja jer su ugrađeni u svaku cijenu u službenom gospodarstvu pa se stoga porezna evazija čini privlačnim sredstvom za poboljšanje financijske situacije. S druge strane, vlasti postavljaju određeni kazneni mehanizam za one koji pokušavaju izbjeći plaćanje poreza. Porezni obveznici moraju vagati između koristi od evazije i rizika da budu uhvaćeni. Stoga je razumno pretpostaviti da povećanje poreznog tereta dovodi do veće sklonosti poreznoj evaziji i veće mogućnosti pojavljivanja skrivene i neformalne proizvodnje, primjerice rada na crno. 
Postoji još jedan razlog zašto je posebno zanimljivo promatrati kakav utjecaj porezi imaju na NOE. Dok se na većinu ekonomskih varijabli može utjecati samo nizom mjera, ishod kojih može biti nesiguran, razinu poreza izravno određuju vlasti.

Utjecaj triju grupa poreza i doprinosa (izravnih i neizravnih poreza te socijalnih doprinosa) trebalo bi promatrati odvojeno. Izravni su porezi oni koje pojedinci i poduzeća izravno plaćaju vlastima npr. porezi na dohodak i dobit. U slučaju neizravnih poreza, onaj tko plaća porez vlastima nije onaj koji snosi porezni teret, nego ustvari posrednik. Najznačajniji neizravni porez u Hrvatskoj je porez na dodanu vrijednost.

Stopa nezaposlenosti definira se kao broj nezaposlenih podijeljen s veličinom aktivnog stanovništva (zbrojem broja nezaposlenih i zaposlenih) i prikazuje se u postocima. Njen utjecaj na neopaženu ekonomiju nije lako predvidjeti. S jedne strane, što je veća stopa nezaposlenosti, više će ljudi tražiti posao u neopaženoj ekonomiji. S druge strane, službeno gospodarstvo i NOE nisu potpuno nepovezani i porast stope nezaposlenosti može biti znak teškoća u čitavom gospodarstvu, pa dobitak u NOE također može biti u opadanju. Isto tako, gubici prihoda uzrokovani nezaposlenošću utječu na potražnju i u službenom i u neslužbenom gospodarstvu. Naposljetku, određenim brojem aktivnosti koje potpadaju pod NOE obično se bave ljudi zaposleni u službenom gospodarstvu pa bi povećanje nezaposlenosti značilo manje mogućnosti za bavljenje tim aktivnostima.

\section{I.2. Indikatori}

Skup indikatora korištenih u radovima koji se bave ovom temom manje-više je standardan.

Bruto domaći proizvod (BDP) ima vezu s veličinom neopažene ekonomije za koju nije posve sigurno je li pozitivna ili negativna, baš kao i u slučaju stope nezaposlenosti. Što je niži BDP, vjerojatnije je da će ljudi tražiti prilike u neopaženoj ekonomiji. Pa ipak, opet treba uzeti u obzir povezanost službenog gospodarstva i NOE. Povoljni ekonomski uvjeti, kao i nepovoljni, podjednako utječu na oboje. Također, primjerice viši prihodi u službenom gospodarstvu mogu rezultirati većom potražnjom za proizvodima iz neopažene ekonomije.

Monetarni agregat Mi općenito uključuje novac u opticaju, putne čekove, a vista depozite i, tamo gdje su dostupni, ATS (Automatic Transfer Service) račune. Mi se koristi kao indikator neopažene ekonomije zato što se smatra da se transakcije u neopaženoj ekonomiji najčešće obavljaju gotovim novcem koji ne povlači za sobom administraciju i teško mu je ući u trag. Povećanje Mi stoga bi ukazivalo na povećanje NOE.

\section{I.3. O izboru varijabli}

Iako bi istraživanje s većim brojem varijabli bilo i zanimljivo i poučno, za to jednostavno nije bilo mogućnosti. Veličine uzoraka koje se u literaturi preporučuju za MIMIC praktički je nemoguće postići u ovom trenu u slučaju Hrvatske čak i kad se koristi MIMIC 4-I-2 model. Veći broj varijabli negativno bi 
utjecao na pouzdanost rezultata. S druge strane, daljnje smanjenje broja varijabli vjerojatno bi bilo kontraproduktivno za istraživanje.

Podaci na koje je model primijenjen su tromjesečni u razdoblju od I998. do 2009. Usprkos činjenici da su neke od varijabli mjerene mjesečno, većina ih je u najboljem slučaju mjerena tromjesečno pa nije bilo moguće povećati veličinu uzorka dodatnim smanjenjem intervala.

\subsection{Prikupljeni podaci}

Nakon što je odlučeno koje će varijable biti korištene kao uzroci i indikatori, valjalo je prikupiti podatke.

Podaci o porezima i doprinosima korišteni u ovom radu su podaci o porezima i doprinosima koji su prikupljeni kao prihodi konsolidirane opće države. Razlog zašto su korišteni prihodi konsolidirane opće države, umjesto proračunskih ili prihoda konsolidirane središnje države, je pretpostavka da porezni obveznici percipiraju poreze jednako, bez obzira u proračunu koje razine vlasti novac u konačnici završi.

Podatke o iznosu prikupljenih poreza pružilo je Ministarstvo financija Republike Hrvatske (http://www.mfin.hr/en/time-series-data). Tromjesečni podaci dostupni su od druge polovine 2004. naovamo. Ostatak vremenskog niza ekstrapoliran je iz godišnjih podataka (http://www.mfin.hr/en/annual-reports-of-ministry-of-finance), koji su dostupni za čitav period 1998-2009, i trendova koji se javljaju među dostupnim tromjesečnim podacima.

Količine prikupljenih izravnih poreza, neizravnih poreza i socijalnih doprinosa u ovom su radu označene sa Dir, Indir i Soc.

Stopa nezaposlenosti u Hrvatskoj varira od izvora do izvora, uslijed razlika u metodologiji. Primjerice, stopa Hrvatskog zavoda za zapošljavanje (HZZ) uvijek je nekoliko postotaka viša od one Državnog zavoda za statistiku (DZS). Na sreću, kretanja su u osnovi jednaka bez obzira na izvor.

Također, kad se stopa jednostavno pokuša izračunati, procjenjivanje veličine aktivnog stanovništva pokazuje se čak složenijim od dolaženja do broja nezaposlenih, kojeg redovito objavljuje HZZ.

Stope nezaposlenosti $\mathrm{u}$ ovom radu (označene $\mathrm{s}$ 'UR' $\mathrm{u}$ izračunima) izvučene su iz publikacija Ministarstva financija RH. Tromjesečne stope nezaposlenosti dostupne su od početka 2004., a ostatak podataka u vremenskom nizu izračunat je koristeći podatke objavljivane u mjesečnim statističkim prikazima Ministarstva (http://www.mfin.hr/en/monthly-statistical-reviews). Valja reći kako se čini da su stope nezaposlenosti objavljene u mjesečnim prikazima tek prilično grube procjene. Često su podložne promjenama u narednim mjesecima i čini se da su u blagom neskladu s godišnjim stopama nezaposlenosti, nakon što ih objavi isti izvor. Kako su te diskrepancije prilično konstantne, mjesečni podaci prilagođeni su sukladno tome, a tromjesečne stope izračunate su iz tih modificiranih mjesečnih stopa. 
Što se tiče bruto domaćeg proizvoda (označenog s GDP), korištena je DZS-ova procjena BDP-a po rashodnoj metodi, u tekućim cijenama (http://www.dzs.hr/default_e.htm). Procjene godišnjeg BDP-a dostupne su za čitavo razdoblje, a procjene tromjesečnog BDP-a od 20oo. nadalje. Procjene tromjesečnog BDP-a za 1998. i 1999. ekstrapolirane su.

Podatke o Mi objavljuje Hrvatska narodna banka (HNB), i to mjesečno (http://www.hnb.hr/publikac/epublikac.htm). Tromjesečni prosjeci korišteni su u modelu.

Izuzev stope nezaposlenosti, svi su gore spomenuti vremenski nizovi monetarni, mjereni u hrvatskim kunama. Svi su takvi vektori prilagođeni koristeći indeks potrošačkih cijena (CPI). CPI mjesečno objavljuje HNB (http://www.hnb.hr/statistika/estatistika.htm). Još jednom, prosječne su vrijednosti korištene za dobivanje tromjesečnih podataka.

Podaci nisu prošli dodatnu prilagodbu na sezonalnost, kako bi ostali što bliže stvarnim vrijednostima i razmjerima. Moguća odstupanja podataka od trendova mogla bi biti značajna prilikom tumačenja rezultata.

Pokrivenost podacima u Hrvatskoj i njihova dostupnost sve su bolje kako vrijeme odmiče i posljednjih su godina postale prilično dobre. Pa ipak, dolaženje do starijih podataka, osobito za intervale kraće od godine, ne prolazi bez poteškoća. Težnja nadležnih institucija ka poboljšanju točnosti i dostupnosti podataka, koja je naravno nužna, ovdje predstavlja problem, zato što metodološke promjene tijekom promatranog razdoblja nipošto ne pridonose očuvanju konzistentnosti podataka. To je nešto što valja imati na umu prilikom razmatranja pouzdanosti konačnih rezultata, no brojne mjere poduzete su u radu ne bi li se osigurala konzistentnost i ne bi li se dobila što bolja procjena vrijednosti potrebnih za primjenu modela.

\subsection{Formiranje kauzalnih i indikatorskih varijabli}

Nakon što su podaci prikupljeni, idući je korak odlučiti kako formirati varijable koje će ući u model.

Kada se pokušavaju utvrditi odnosi među varijablama, ono što je bitno su njihovi trendovi, a ne jedinice u kojima se mjere. Primjerice, kad se pokušava odlučiti kako što uspješnije reklamirati i prodavati proizvode, moglo bi se pokušati procijeniti kako na tržišni udio mjeren u postocima, utječe cijena proizvoda mjerena u kunama, ukupna duljina emitiranih reklama mjerena u sekundama, veličina novinskih oglasa i broj podijeljenih letaka.

Ono što se zapravo utvrđuje je kako na zavisnu varijablu utječe promjena vrijednosti nezavisne varijable. Valjani zaključci mogu biti izvučeni sve dok je poznato u kojim su jedinicama mjerene vrijednosti ulaznih varijabli modela.

No, ovdje se javlja poteškoća prilikom korištenja MIMIC modela. Ni u jednom trenu nije izravno procijenjena veza između latentne varijable i ostalih varijabli. Inicijalna forma kauzalnih i indikatorskih varijabli može uvelike varirati. Uzrok ili indikator može ustvari biti kombinacija više varijabli npr. omjer. Može biti logaritam varijable, razlika i sl., u ovisnosti o tome što autor studije smatra 
najprimjerenijim za svoje podatke. Zatim, kako bi se osigurala stacionarnost, neki od njih mogu biti dalje diferencirani jednom, neki više nego jednom, a neki možda uopće nisu diferencirani. Stoga, nakon što su svi uzroci i indikatori poprimili svoj konačan oblik, ne mora uopće biti jasno u kojem je obliku latentna varijabla.

To je značajna stvar, budući da ako nije jasno kako interpretirati procijenjene vrijednosti $\left(\hat{\eta}_{\mathrm{t}}=\hat{\gamma}^{\prime} \mathrm{x}_{\mathrm{t}}\right)$, sama procjena postaje praktički beskorisna.

U slučaju kad latentna varijabla predstavlja veličinu NOE, interpretacija izlaznih vrijednosti modela može se iz temelja razlikovati od studije do studije. Iako su u većini slučajeva vrijednosti interpretirane kao postotni udio prihoda neopažene ekonomije u BDP-u, u nekim slučajevima interpretiraju se kao sam prihod NOE mjeren u novcu².

Čini se nužnim učiniti primjenu modela intuitivno što jednostavnijom i pokušati izbjeći probleme s interpretacijom izlaznih vrijednosti. Stoga su sve varijable u ovom radu formirane iz prikupljenih podataka na isti način, kao stope rasta:

$$
\frac{\Delta T_{t}}{T S_{t-1}}=\frac{T_{t}-T S_{t-1}}{T_{t-1}}:=\left[\frac{T S_{1}-T_{0}}{T S_{0}}, \ldots, \frac{T_{i}-T S_{i-1}}{T S_{i-1}}, \ldots, \frac{T S_{n-1}-T S_{n-2}}{T S_{n-2}}\right]^{\prime}
$$

pri čemu je n duljina uzorka (48), a TS $\mathrm{t}_{\mathrm{t}}=\mathrm{Dir}_{\mathrm{t}}$, Indir ${ }_{\mathrm{t}}, \mathrm{Soc}_{\mathrm{t}}, \mathrm{UR}_{\mathrm{t}}, \mathrm{GDP}_{\mathrm{t}}, \mathrm{MI}_{\mathrm{t}}$.

Takav izbor forme varijabli detaljnije je objašnjen u Dodatku I.

\subsection{Testiranje varijabli}

Nakon što je izabrana početna forma uzroka i indikatora, uobičajeno je testirati njihovu stacionarnost, iako Breusch dovodi u sumnju smislenost postupka. Koristeći prošireni Dickey-Fuller (ADF) test (s konstantom (C) i konstantom i trendom (C\&T)) i Phillips-Perronov test:

\section{Tablica I.}

Rezultati ADF i Phillips-Perronovog testa

\begin{tabular}{|c|c|c|c|c|c|c|}
\hline Testna jedn. & $\frac{\Delta \operatorname{Dir}_{t}}{\operatorname{Dir}_{t}}$ & $\frac{\Delta \text { Indir }_{t}}{\text { Indir }_{t}}$ & $\frac{\Delta \operatorname{Soc}_{t}}{\operatorname{Soc}_{t}}$ & $\frac{\Delta \mathrm{UR}_{\mathrm{t}}}{\mathrm{UR}_{\mathrm{t}}}$ & $\frac{\Delta \mathrm{GDP}_{\mathrm{t}}}{\mathrm{GDP}_{\mathrm{t}}}$ & $\frac{\Delta \mathbf{M} 1_{t}}{M 1_{t}}$ \\
\hline $\mathrm{ADF} C$ & -5.85 & $-\mathrm{I} 3.40$ & -6.70 & -6.62 & -14.89 & -6.59 \\
\hline ADF C\&T & $-5.8 \mathrm{I}$ & $-\mathrm{I} 3.24$ & -6.62 & -6.62 & -15.34 & -7.28 \\
\hline PP t-omjer & -I8.6o & -3.37 & -6.99 & $-7.4 \mathrm{I}$ & -15.45 & -2.52 \\
\hline
\end{tabular}

Izvor: Vlastiti izračun.

\footnotetext{
${ }^{2}$ Ne nužno kao postotni udio ili prihod, nego češće kao neka funkcija postotnog udjela ili prihoda.
} 
može se zaključiti da su sve varijable stacionarne. Vrijednost od -2.52I4 dobivena u PP - testu za stopu rasta Mı je granična, no softver korišten za provjeru prisutnosti jediničnog korijena spajajući oba testa svejedno sugerira kako bi nul-hipotezu o prisutnosti jediničnog korijena trebalo odbaciti.

Nadalje, Engle-Granger pristup korišten je kako bi se provjerilo jesu li svi uzroci kointegrirani sa svakim od indikatora. Načini se regresija između uzroka i svakog od indikatora:

$$
\begin{aligned}
& \frac{\Delta \mathrm{GDP}_{\mathrm{t}}}{\mathrm{GDP}_{\mathrm{t}}}=\alpha_{1} \frac{\Delta \mathrm{Dir}_{\mathrm{t}}}{\operatorname{Dir}_{\mathrm{t}}}+\alpha_{2} \frac{\Delta \operatorname{Indir}_{\mathrm{t}}}{\operatorname{Indir}_{\mathrm{t}}}+\alpha_{3} \frac{\Delta \mathrm{Soc}_{\mathrm{t}}}{\operatorname{Soc}_{\mathrm{t}}}+\alpha_{4} \frac{\Delta \mathrm{UR}_{\mathrm{t}}}{\mathrm{UR}_{\mathrm{t}}}+\mathrm{u}_{1} \\
& \frac{\Delta \mathrm{M} 1_{\mathrm{t}}}{\mathrm{M} 1_{\mathrm{t}}}=\beta_{1} \frac{\Delta \mathrm{Dir}_{\mathrm{t}}}{\mathrm{Dir}_{\mathrm{t}}}+\beta_{2} \frac{\Delta \operatorname{Indir}_{\mathrm{t}}}{\operatorname{Indir}_{\mathrm{t}}}+\beta_{3} \frac{\Delta \mathrm{Soc}_{\mathrm{t}}}{\mathrm{Soc}_{\mathrm{t}}}+\beta_{4} \frac{\Delta \mathrm{UR}_{\mathrm{t}}}{\mathrm{UR}_{\mathrm{t}}}+\mathrm{u}_{2},
\end{aligned}
$$

parametri regresije procijene $\left(\alpha_{\mathrm{I}}=-0.1069, \alpha_{2}=0.5 \mathrm{I} 8 \mathrm{I}, \alpha_{3}=-0.5 \mathrm{I} 84, \alpha_{4}=-0.4772, \beta_{\mathrm{I}}=-0.0723, \beta_{2}=0.1456\right.$, $\beta_{3}=$ 0.972I, $\beta_{4}=-0.1209$ ) $\mathrm{i}$ dobiju se reziduali $\mathrm{u}_{\mathrm{I}} \mathrm{i} \mathrm{u}_{2}$

Zatim se na rezidualima provodi $\mathrm{ADF}$ test i ako je nul-hipoteza o jediničnom korijenu odbijena, uzroci su kointegrirani s indikatorima. Ishod je testa $(\mathrm{ADFI}=-4.8968, \mathrm{ADF} 2=-4.0772)$ da su uzroci kointegrirani s indikatorima.

Ovaj se postupak rijetko koristi, ali pomaže pokazati da izbor varijabli stvarno ima smisla. Također je obvezan prilikom korištenja nekih modifikacija MIMIC modela, primjerice EMIMIC-a, verzije MIMIC-a kreirane za dugoročne podatke, koju su predstavili Buehn i Schneider 20o8. godine.

Svi se uzroci i indikatori mogu zadržati kao ulazne varijable, a njihova forma ostaje nepromijenjena. Uzevši u obzir formu ulaznih varijabli modela, izlaz modela mora se interpretirati kao:

$\eta_{\mathrm{t}}=\frac{\Delta \mathrm{NOE}_{\mathrm{t}}}{\mathrm{NOE}_{\mathrm{t}-1}}=\frac{\mathrm{NOE}_{\mathrm{t}}-\mathrm{NOE}_{\mathrm{t}-1}}{\mathrm{NOE}_{\mathrm{t}}}$ - stopa rasta prihoda NOE prilagođenog koristeći CPI. 
Slika 3.

Struktura modela primijenjenog na hrvatsko gospodarstvo i pretpostavljene veze među varijablama

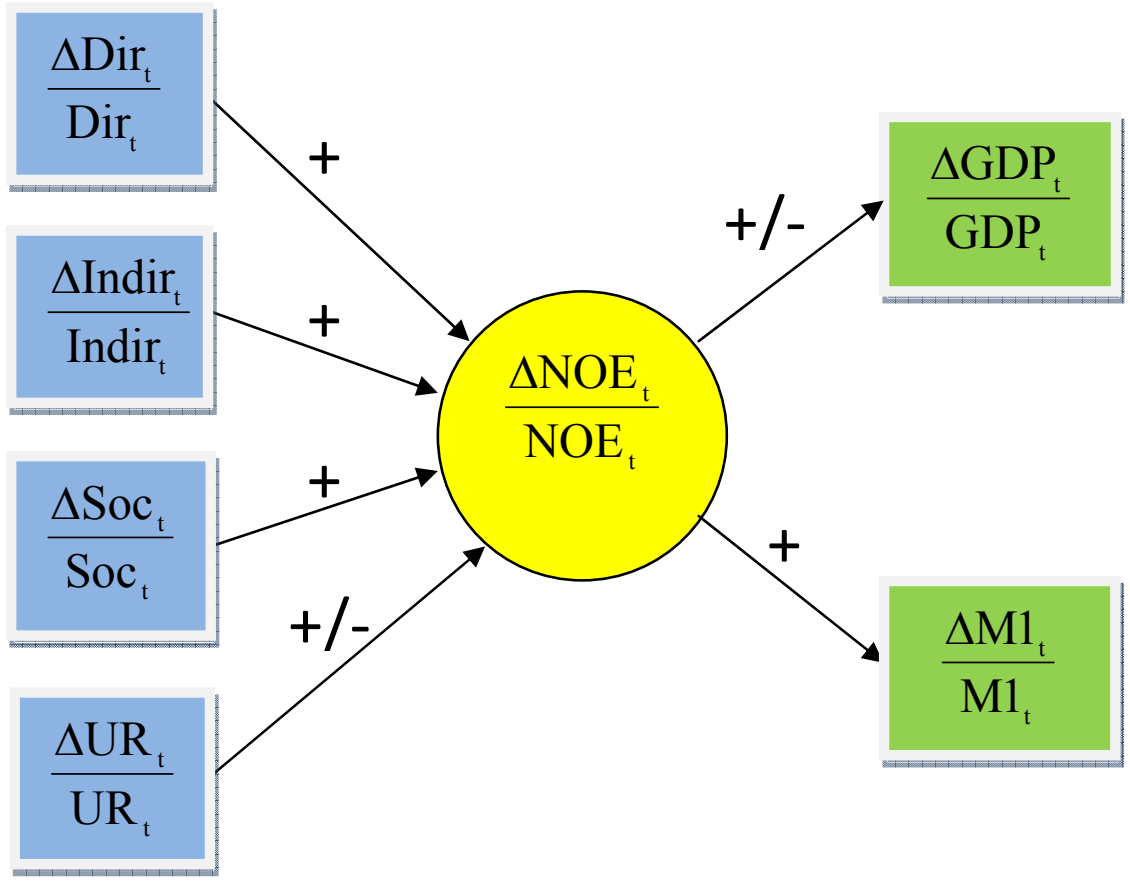

Izvor: Vlastito formiranje varijabli i pretpostavke.

\subsection{Procjenjivanje parametara}

Sad se podaci mogu ubaciti u računalo kako bi parametri mogli biti procijenjeni. U tu svrhu korišten je program LISREL, jedno od češćih pomagala za SEM modeliranje.

U slučaju da nije nametnut uvjet normalizacije, rezultati procjene parametara su sljedeći:

Tablica 2.

Parametri dobiveni bez normalizacije

\begin{tabular}{|l|c|c|c|c|c|c|}
\hline Varijable & $\frac{\Delta \text { Dir }_{\mathbf{t}}}{\text { Dir }_{\mathbf{t}}}$ & $\frac{\Delta \text { Indir }_{\mathbf{t}}}{\text { Indir }_{\mathbf{t}}}$ & $\frac{\Delta \text { Soc }_{\mathbf{t}}}{\mathbf{S o c}_{\mathbf{t}}}$ & $\frac{\Delta \mathbf{U R}_{\mathbf{t}}}{\mathbf{U R}_{\mathbf{t}}}$ & $\frac{\Delta \mathbf{G D P}_{\mathbf{t}}}{\mathbf{G D P}_{\mathbf{t}}}$ & $\frac{\Delta \mathbf{M 1}_{\mathbf{t}}}{\mathbf{M 1}_{\mathbf{t}}}$ \\
\hline Parametri & -0.02 & 0.07 & -0.06 & -0.07 & 7.13 & 4.10 \\
\hline T-vrijednosti & $-3.8 \mathrm{I}$ & 8.26 & $-2 . \mathrm{II}$ & $-4.9 \mathrm{I}$ & - & 4.92 \\
\hline
\end{tabular}

Izvor: Vlastiti izračun

Nakon korištenja konvencije koju su uveli Giles i Tedds (2002.), postavljanjem koeficijenta ispred stope Mı indikatora na +I, dobivene su sljedeće procjene:

${ }^{3}$ Stope rasta unesene su u program u obliku postotka. 
Tablica 3.

Parametri dobiveni uz normalizaciju koeficijenta ispred stope od MI

\begin{tabular}{|l|c|c|c|c|c|c|}
\hline Varijable & $\frac{\Delta \mathbf{D i r}_{\mathbf{t}}}{\mathbf{D i r}_{\mathbf{t}}}$ & $\frac{\Delta \mathbf{I n d i r}_{\mathbf{t}}}{\mathbf{I n d i r}_{\mathbf{t}}}$ & $\frac{\Delta \mathbf{S o c}_{\mathbf{t}}}{\mathbf{S o c}_{\mathbf{t}}}$ & $\frac{\Delta \mathbf{U R}_{\mathbf{t}}}{\mathbf{U R}_{\mathbf{t}}}$ & $\frac{\Delta \mathbf{G D P}_{\mathbf{t}}}{\mathbf{G D P}_{\mathbf{t}}}$ & $\frac{\boldsymbol{\Delta M 1 _ { \mathbf { t } }}}{\mathbf{M 1}_{\mathbf{t}}}$ \\
\hline Parametri & -0.07 & 0.29 & -0.25 & -0.28 & $\mathrm{I} .74$ & 1.00 \\
\hline T-vrijednosti & -3.16 & 4.66 & -1.98 & -3.70 & 4.92 & - \\
\hline
\end{tabular}

Očekivan je pozitivan predznak koeficijenta ispred varijable stope rasta MI, za razliku od onog ispred stope BDP-a, gdje su moguća oba predznaka. Stoga je Mı izabran za normalizaciju.

Prilikom primjene modela došlo je do nekih pojava karakterističnih za malu veličinu uzoraka. Prilagodba odnosno fit nije sjajan uz vrijednost standardizirane prosječne kvadratne kovarijance reziduala (RMSEA) od o.259, dok je hi-kvadrat vrijednost 12.24, što je sve očekivano. Naizgled najveći problem blago je negativna varijanca pogreške. To se također može pripisati maloj veličini uzorka. Van Driel (1978) predlaže da bi se u takvim slučajevima trebao formirati pouzdani interval temeljen na standardnoj pogreški varijance pogreške. Ako taj interval uključuje nulu, zaključuje se da je varijanca pozitivna, ali blizu nuli, i da je negativna procjena stvar slučajnosti. Sličan postupak predlažu i Chen i dr. (200I).

Varijanca pogreške procijenjena je na -0.27 uz standardnu pogrešku od 4.58 u normaliziranom modelu (i -0.0053 uz standardnu pogrešku od o.09 u nenormaliziranom). Stoga se mogu koristiti Van Drielovi zaključci.

Predznaci nekih od parametara, točnije onih za izravne poreze i socijalne doprinose donekle su neočekivani i mora im se posvetiti dodatna pažnja. Ti predznaci zapravo nisu niti neobjašnjivi, niti nezabilježeni u drugim studijama.

Primjerice, što se socijalnih doprinosa tiče, više prikupljenih doprinosa značilo bi u konačnici više primljenih doprinosa, što bi u teoriji trebalo značiti manju potrebu za okretanje neopaženoj ekonomiji. No, ovdje se uvijek javlja pitanje broja primatelja doprinosa. Igrom slučaja, upravo omjer onih koji pridonose i onih koji koriste socijalne doprinose predstavlja trenutno priličan problem u Hrvatskoj.

Izravni porezi i socijalni doprinosi veoma su slične varijable i često se čak promatraju kao jedinstvena varijabla, uslijed sličnih načina i dinamike plaćanja. Jedno od mogućih objašnjenja ovakvog njihovog odnosa prema neopaženoj ekonomiji je da je iznos prikupljenih izravnih poreza i socijalnih doprinosa u stvari indikativan za veličinu opaženih, registriranih aktivnosti, koje pripadaju službenom gospodarstvu, nasuprot onima koje pripadaju neopaženoj ekonomiji. Posebno bi mogla biti indikativan za broj radnika koji su prijavljeni i rade u službenom gospodarstvu, umjesto rada na crno.

Povećanje npr. rada na crno svakako vodi smanjenju iznosa prikupljenih poreza. Također, ako su ostale ekonomske varijable, uključujući stopu nezaposlenosti, fiksirane, i porezne stope se nisu mijenjale, smanjenje iznosa prikupljenih izravnih poreza i socijalnih doprinosa lagano se može pripisati povećanju neopaženih aktivnosti. To se može prikazati sljedećim dijagramima: 


\section{Slika 4.}

Veza između iznosa prikupljenih izravnih poreza i socijalnih doprinosa i prihoda neopažene ekonomije ${ }^{4}$

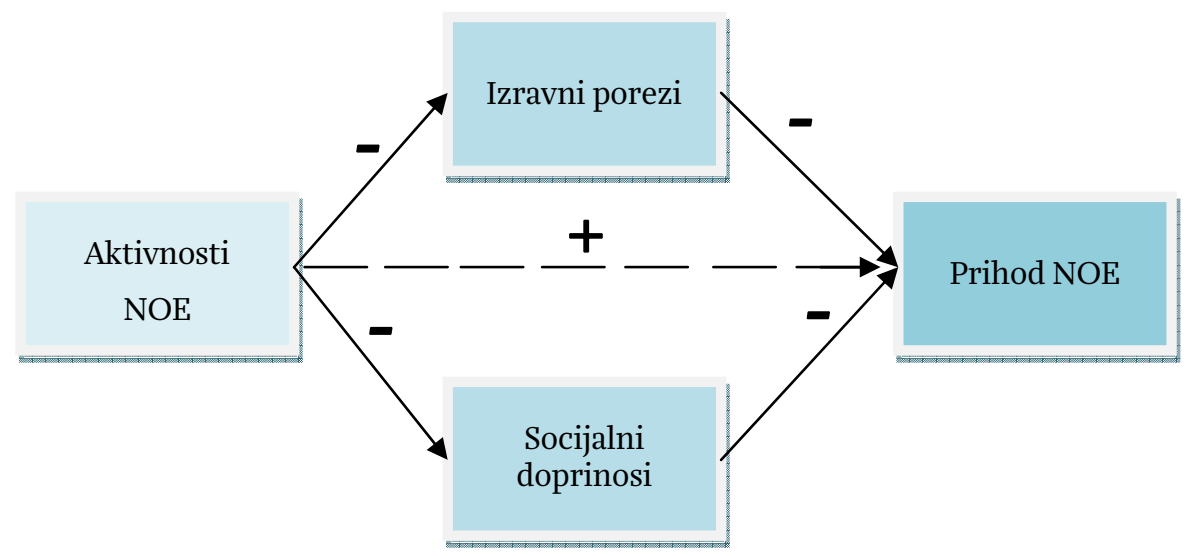

Izvor: Vlastita pretpostavka.

Iako ovo može objasniti uočene odnose, to definitivno nije njihov jedini uzrok. Cichocki (2008) bavi se sivom ekonomijom u Poljskoj, kao i njenim vezama s državnim proračunom i poreznim sustavom. Njegov je rad uključivao izgradnju vektorskog autoregresivnog modela i crtanja impulsnih reakcijskih funkcija. Koristeći njih, otkrio je da siva ekonomija raste porastom efektivne stope neizravnih poreza. S druge strane, odgovor sive ekonomije na impuls efektivne stope izravnih poreza (njeno povećanje) vodi smanjenju veličine sive ekonomije. Stoga je zaključio kako postoji pozitivna veza između sive ekonomije i poreznog tereta uzrokovanog neizravnim porezima i negativna veza između sive ekonomije i poreznog tereta uzrokovanog izravnim porezima.

Teorija prikazana na slici 4 ne objašnjava rezultate do kojih je došao Cichocki (2008), budući da je on kao mjere poreznog tereta koristio porezne stope. To bi značilo da su korijeni ovog odnosa dublji nego što se prvotno očekivalo i vjerojatno bi trebali biti predmetom zasebnog istraživanja, no taj odnos svejedno postoji.

\subsection{Prilagodba}

Ranije je spomenuto kako je dio privlačnosti MIMIC modela u tome što se čini da taj model istovremeno daje i procjenu veličine neopažene ekonomije i njenu vezu s drugim varijablama. MIMIC u tom pogledu ne ispunjava do kraja očekivanja. Iako može procijeniti veze neopazive varijable prema drugim varijablama, kao i njene trendove, njena stvarna razina tj. stvarne vrijednosti koje poprima ostaju nepoznate. Kako bi se došlo do njih, ipak je potrebno opažanje neopazive varijable. Drugim riječima, MIMIC-u je potrebna druga metoda procjenjivanja, čiji se rezultati zatim koriste kao referentne vrijednosti.

Načini prilagodbe prema referentnim vrijednostima variraju od studije do studije, ali se u osnovi svode na dvije metode. Pripadni element vremenskog niza kojeg je izbacio MIMIC na razinu referentne

\footnotetext{
${ }^{4}$ Prikazana je veza rezultat odnosa između aktivnosti NOE i količine prikupljenih izravnih poreza i socijalnih doprinosa i veze između aktivnosti NOE i prihoda NOE.
} 
vrijednosti dolazi ili množenjem (I) ili zbrajanjem (2). Isti postupak zatim se primjenjuje na ostatak vremenskog niza:

(I) $\quad \frac{\mathrm{Val}_{\mathrm{tbm}}}{\widetilde{\eta}_{\mathrm{tbm}}}=\mathrm{c}$

$\tilde{\eta}^{(\mathrm{bm})}=\mathrm{c}^{*} \tilde{\eta}$

ili

(2) $\quad \mathrm{Val}_{\mathrm{tbm}}-\widetilde{\eta}_{\mathrm{tbm}}=\mathrm{a}$

$\widetilde{\eta}_{\mathrm{i}}^{(\mathrm{bm})}=\widetilde{\eta}_{\mathrm{i}}+\mathrm{a}$

pri čemu su Val $\mathrm{tbm}_{\mathrm{tbm}}$ - referentna vrijednost za trenutak tbm, $\widetilde{\eta}$ - vrijednosti koje je dao MIMIC, a $\widetilde{\eta}^{\text {(bm) }}$ - prilagođene vrijednosti.

Iako se ponekad čini kao zgodan izbor, valja istaknuti da rezultati prilagodbe zbrajanjem nisu u potpunosti nezavisne od izbora indikatorske varijable koju se normalizira.

Vrijednosti korištene kao referentne u ovom radu dobili su Lovrinčević, Mikulić i Nikšić-Paulić (2002.), primjenom Eurostatove metode. Zanimljivo je uočiti kako se razine neopažene ekonomije procijenjene pomoću više metoda poklapaju u razdoblju 1998. - 2000., i to se razdoblje čini logičnim izborom za uzimanje referentne vrijednosti. Rad Lovrinčevića, Mikulića i Nikšić-Paulić obuhvaća 1998. i 1999. godinu i donosi procjene od $8.9 \%$ i $8.1 \%$.

Mađarević-Šujster i Mikulić (200I.) daju procjenu od 9.I \% odnosno 8.4 \% za te dvije godine koristeći SNA metodu. Do sličnih rezultata Mađarevic-Šujster (200I.) došla je i mjereći poreznu evaziju (gornja granica). I SNA metoda i metoda porezne evazije pokazuju da razina NOE u 20oo. godini pada na nešto ispod $7 \%$. 


\section{Slika 5.}

Procjene NOE u Hrvatskoj korištenjem raznih metoda, 1990-2000.

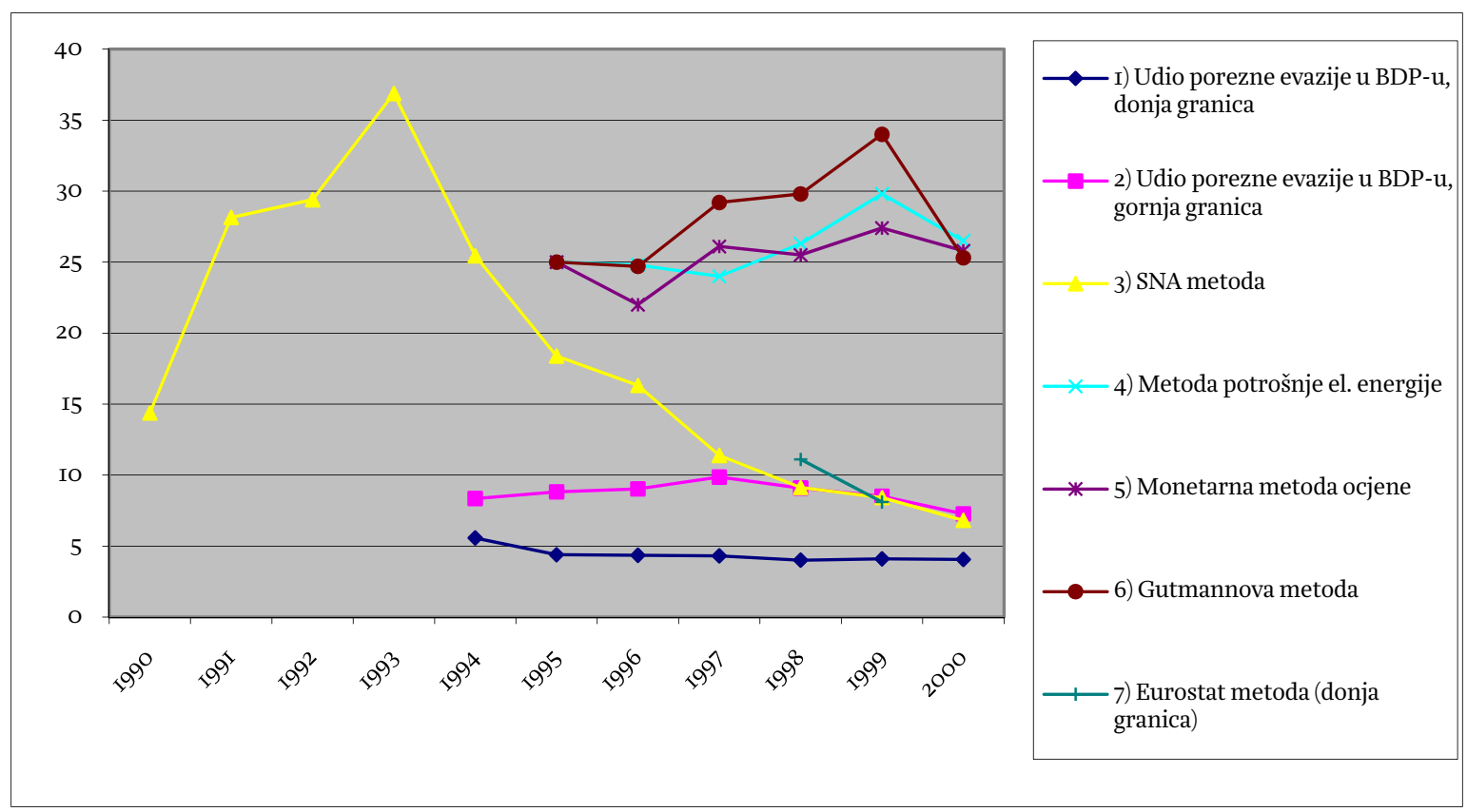

Izvor: Ott (2002).

Procjene dobivene Gutmannovom metodom, monetarnom metodom ocjene i metodom potrošnje električne energije su malo više disperzirane, ali još uvijek prilično blizu jedne drugima u tom razdoblju, samo što je procijenjena razina viša. Međutim, primjerenost ovih metoda hrvatskom gospodarstvu u najboljem je slučaju upitna. s druge strane, Eurostatova je metoda jedna od najpotpunijih i najopsežnijih metoda procjene neopažene ekonomije i stoga je izabrana za izvor referentne vrijednosti u ovom radu.

Procijenjene vrijednosti u ovom su slučaju interpretirane kao stope rasta na tromjesečnoj razini, što u kombinaciji s referentnim vrijednostima na godišnjoj razini dovodi do složenog postupka prilagodbe.

Prilagodba množenjem vjerojatno je optimalna metoda ${ }^{5}$, pa će biti korištena u ovom radu. Rezultat postupka isti je bez obzira na to koji je indikator normaliziran, a prilagodba ne utječe na omjere među članovima procijenjenog niza. U ovom slučaju morat će se koristiti više od jedne referentne vrijednosti jer valja odrediti dvije nepoznate vrijednosti. Jedna je koeficijent kojeg treba koristiti za modifikaciju stopa, a druga prihod u vrijeme jednog od perioda, kako bi ostali mogli biti ekstrapolirani. Postupak prilagodbe detaljno je prikazan u Dodatku 3.

Rezultati postupka prilagodbe prikazani su na slikama 6-8.

Referentne vrijednosti pomoću kojih se došlo do tih rezultata donje su granične procjene za 1998. i 1999. godinu i stoga, kao proširenje te procjene, dobivene vrijednosti također treba promatrati kao donje granične procjene.

\footnotetext{
${ }^{5}$ Vidi Dodatak 2.
} 


\section{Slika 6.}

Procjena tromjesečnog prihoda NOE u odnosu na službeni BDP, 1998-20o9.

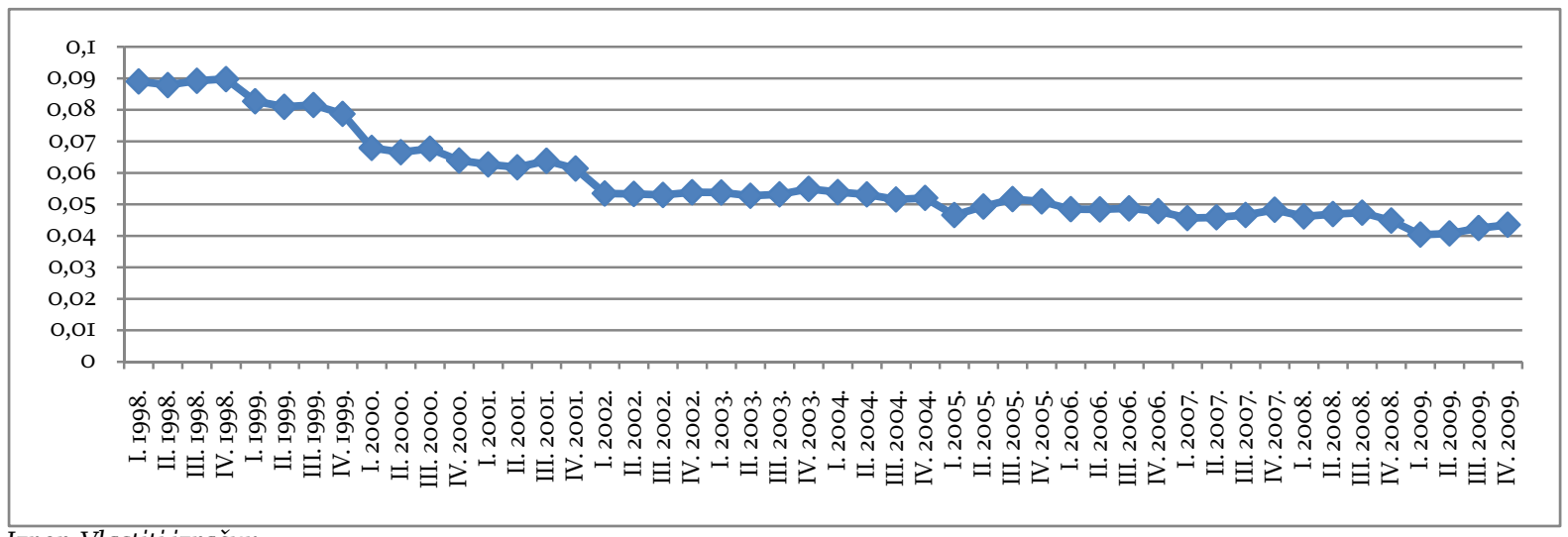

Izvor: Vlastiti izračun.

\section{Slika 7.}

Procjena godišnjeg prihoda NOE, 1998-2009.

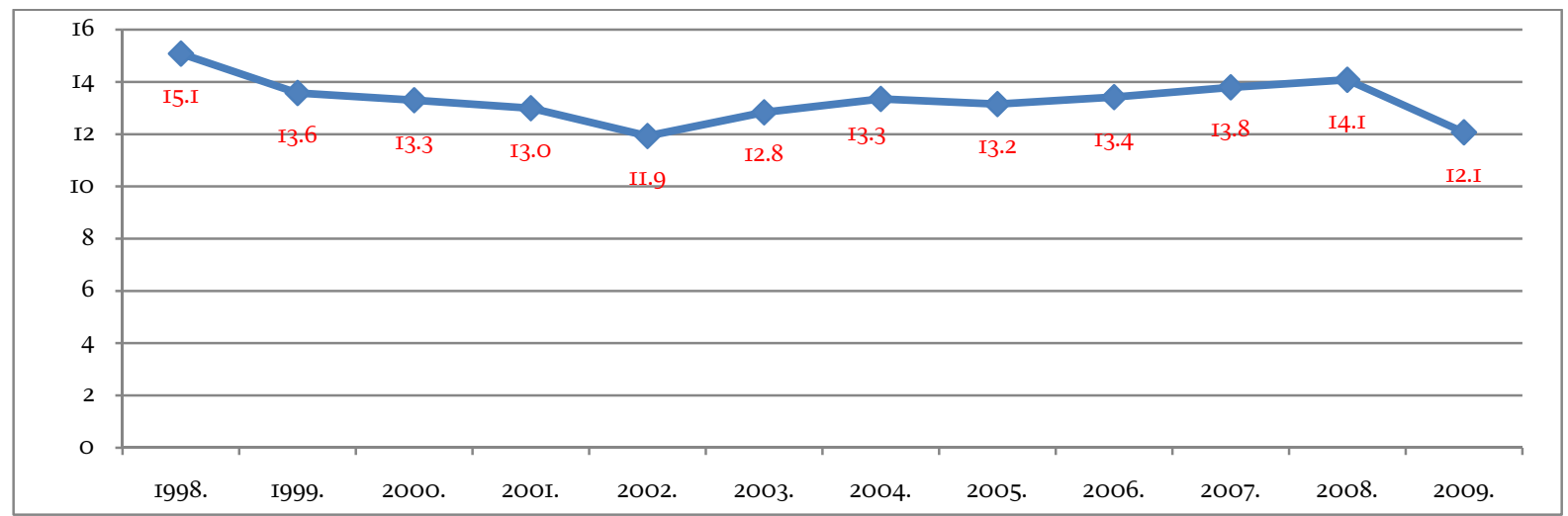

Izvor: Vlastiti izračun.

\section{Slika 8.}

Procjena godišnjeg prihoda NOE u odnosu na službeni BDP, 1998-2009.

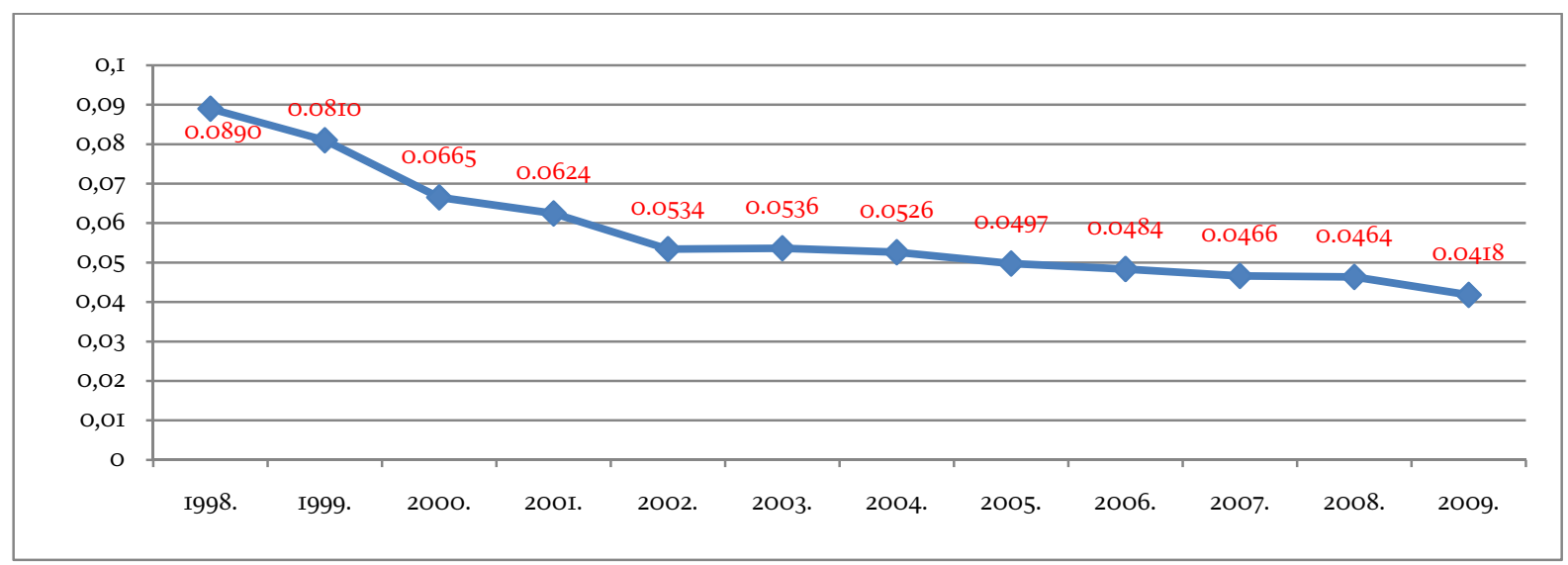

Izvor: Vlastiti izračun 


\subsection{O rezultatima}

Dobiveni procjene izravna su posljedica procesa prilagodbe i referentnih vrijednosti, a ne neovisne procjene. Prve dvije godišnje vrijednosti su naravno identične onima koje su dobili Lovrinčević, Mikulić i Nikšić-Paulić (2002). Treća godišnja vrijednost (za 2000. godinu) bliska je onima dobivenim SNA metodom i gornjom graničnom procjenom porezne evazije. Budući da je razdoblje 1998-2009. pod povećalom, stječe se dojam da je omjer prihoda NOE i službenog BDP-a padao prilično naglo do 2002. godine, a poslije toga ušao u razdoblje tek blagih promjena do 2008. Sagleda li se veća slika, niti u jednom razdoblju nisu prisutne drastične promjene i rezultati su prilično stabilni.

Još jedan razmjerno velik pad neočekivano se dogodio 2009. godine u odnosu na 2008. godinu. Iako su se i prihod NOE i BDP smanjili, čini se da je osjetniji bio pad prihoda NOE. Za takav rezultat može biti više objašnjenja. Jedno je da MIMIC pristup nije najprimjereniji za mjerenje veličine neopažene ekonomije i da ustvari više odražava trendove drugih ekonomskih indikatora nego što daje procjenu stvarne veličine $\mathrm{NOE}^{6}$. Drugi razlog mogao bi biti čisto statističke prirode, budući da su podaci za 2009. godinu još svježi i podložni promjenama.

Gledamo li na rezultate kao ispravne, postoje i neka ekonomska objašnjenja. Kao prvo, lako je moguće da su ekonomska kriza i mjere za njeno suzbijanje potresle i zbunile čitavo gospodarstvo i da će još trebati vremena da se svi ekonomski subjekti prilagode novonastaloj situaciji. Neke od varijabli korištenih za modeliranje NOE vjerojatno zaostaju u pokazivanju posljedica globalnih ekonomskih pojava, poput krize. Sama neopažena ekonomija u stvarnosti vjerojatno zaostaje još i više, trebajući vrijeme da odgovori na značajne promjene u vrijednosti svojih uzroka. Uzevši u obzir raznolikost aktivnosti u neopaženoj ekonomiji, također je zamislivo da su se, onog trenutka kad se kriza pojavila i kad su bili potrebni rezovi, ljudi prvo odrekli nekih aktivnosti iz domene NOE. I onih aktivnosti koje su ne-ekonomske prirode (npr. prostitucija i povremena zlouporaba droge (T7) ili čak napojnice (T8)), i onih koje su ekonomske. Što se ekonomskih aktivnosti tiče, vjerojatno je lakše otpustiti neprijavljenog radnika, nego prijavljenog, koji ima određena prava, donekle je zaštićen zakonom, a možda i od strane sindikata. No, to su sve kratkoročne mjere. Dugoročno, u duljim razdobljima krize, aktivnosti neopažene ekonomije nedvojbeno bi cvjetale, a njihov omjer sa službenim BDP-om trebao bi rasti. Gledajući tromjesečni omjer prihoda NOE i BDP-a u 2009. godini, čini se da se upravo to događa. Rast tijekom tri uzastopna tromjesečja najdulji je period rasta u dobivenoj procjeni.

Također valja napomenuti kako MIMIC pristup dopušta iznenađujuće velik broj implementacijskih strategija i postupaka, osobito kad je riječ o formiranju ulaznih varijabli i procesu prilagodbe. Ili preciznije, velik je broj implementacijskih strategija do sad korišten od strane raznih istraživača koji su koristili MIMIC pristup. Na tu slobodu u postupku implementacije može se gledati kao na nedostatak ili kao na prednost, budući da ekonomija kao znanost nije ni izbliza toliko stroga kao matematika. No, ona, bez sumnje, baca sjenu na pouzdanost procjene kojom model rezultira. Stoga bi vjerojatno bilo dobro poraditi na standardizaciji postupka kako bi se ove poteškoće u budućnosti izbjegle.

\footnotetext{
${ }^{6}$ Vidi točku 4.2 i dodatak 4.
} 


\section{Zaključak}

Od prvog istraživanja neopažene ekonomije i pokušaja da je se izmjeri, istraživači su pristupali tom problemu sa raznih strana, koristeći različite pristupe i još uvijek nije nađen optimalan pristup oko kojeg bi se svi složili. U ovom radu naglasak je bio na MIMIC pristupu. Je li se MIMIC pokazao boljim ili lošijim od ostalih metoda? To ovisi o tome što se od njega očekuje. Vjerojatno funkcionira najbolje kad ga se koristi na starijim, dobro razvijenim i uhodanim gospodarstvima, uz koja se mogu vezati dulji, stabilniji vremenski nizovi. No, to vrijedi za većinu metoda.

Ono što MIMIC može, bez bilo kakve pomoći izvana, je procijeniti veze između latentne varijable i njenih uzroka i indikatora. Dok je većina veza koje je izbacio model očekivana, procijenjena je zanimljiva negativna veza između izravnih poreza i neopažene ekonomije te između socijalnih doprinosa i neopažene ekonomije. Čini se da je ta veza prisutna u gospodarstvima tranzicijskih zemalja.

MIMIC bi ipak trebalo promatrati više kao dodatak drugim metodama za procjenjivanje NOE, nego kao samostalnu metodu. Primjerice, opsežne metode koje daju detaljne procjene NOE obično pokrivaju veoma kratka vremenska razdoblja, najčešće tek godinu ili dvije. MIMIC može uspješno služiti kao dodatak tim metodama i proširivati njihove rezultate na dulja vremenska razdoblja.

MIMIC je na taj način iskorišten u ovom radu, koristeći raniju donju graničnu procjenu NOE $u$ Hrvatskoj za 1998. i 1999. godinu, dobivenu Eurostatovom metodom, kao referentnu vrijednost i proširujući tu procjenu na godine 2000-2009. Nakon značajnog pada u prvih nekoliko godina pokrivenih ovom studijom, omjer prihoda NOE i službenog BDP-a zadržao se gotovo na istoj razini od 2002. godine. Model također upućuje na to da je prihod NOE osjetno pao dolaskom globalne krize, čak više od službenog BDP-a, uzrokujući još jedno značajno relativno smanjenje. Pa ipak, taj će trend vjerojatno prestati u narednom razdoblju, ako je suditi po tromjesečnim omjerima. 


\section{Dodatak I.}

\section{Objašnjenje izbora stopa rasta za ulazne varijable modela}

Izbor stopa rasta vrijednosti uzoraka za ulazne varijable mogao bi se smatrati blago kontroverznim, osobito kad je riječ o porezima. Čini se kako sam iznos prikupljenih poreza i nije baš mjera poreznog tereta i da bi per capita vrijednosti bile primjerenije za taj zadatak, bilo da su korištene umjesto stopa rasta ili da se koriste stope rasta per capita vrijednosti:

$$
\frac{\Delta \operatorname{Tax}_{t}}{\operatorname{Tax}_{t-1}} \mapsto \frac{\operatorname{Tax}_{t}}{\operatorname{Pop}_{t}} \quad \text { ili } \quad \text { (2) } \frac{\Delta \operatorname{Tax}_{t}}{\operatorname{Tax}_{t-1}} \mapsto \frac{\Delta\left(\frac{\operatorname{Tax}_{t}}{\operatorname{Pop}_{t}}\right)}{\frac{\operatorname{Tax}_{t-1}}{\operatorname{Pop}_{t-1}}}
$$

Može se tvrditi kako su iznosi prikupljenih poreza podložni vanjskim utjecajima, kao što je nagla promjena broja stanovnika. No, takve bi se promjene osjetile u čitavom modelu i utjecale bi podjednako na sve varijable. Također, veličina je stanovništva još jedna varijabla koju je moguće samo grubo procijeniti, barem u razdobljima između popisa stanovništva. Kad se te procjene uzmu u obzir, čini se kako broj stanovnika poslijeratne Hrvatske, iako konstantno u blagom opadanju, ne fluktuira ni izbliza dovoljno da bi ozbiljnije utjecao na izračunate stope rasta, pa da bi promjena (2) bila relevantna?. Također, ako su neke varijable stvorene i prikazane iz perspektive prosječnog pojedinca, dok su druge na razini države, nije baš osobito jasno kako interpretirati izlazne varijable modela, osobito ako se provede (I).

Najuobičajenija forma varijabli vezanih uz porez u ovoj vrsti istraživanja iznos je prikupljenih poreza u odnosu na BDP:

$$
\text { (3) } \frac{\Delta \operatorname{Tax}_{t}}{\operatorname{Tax}_{t-1}} \mapsto \frac{\operatorname{Tax}_{t}}{\operatorname{GDP}_{t}}
$$

Ovdje se može koristiti slično rezoniranje kao ranije. Ako se neke varijable, poput poreza, prikazuju u odnosu na BDP, dok druge, poput stope nezaposlenosti, jednostavno ne mogu biti korištene na taj način, javljaju se sumnje oko prirode izlaznih vrijednosti modela.

Ovdje u igru ulazi i veza izabranih indikatorskih varijabli s latentnom varijablom. Kao što je ranije spomenuto, odnos između BDP-a i veličine NOE opisuje se i kao pozitivan i kao negativan. Do negativne veze dolazi zato što smanjenje BDP-a gura ljude prema neopaženoj ekonomiji. To znači da bi smanjenje BDP-a ukazivalo i na povećanje prihoda NOE i povećanje prihoda NOE u odnosu na BDP. Pozitivan odnos objašnjava se vezama između službene i neopažene ekonomije. Po toj interpretaciji, povećanje BDP-a ukazuje na povoljne uvjete u čitavom gospodarstvu i stoga povećanje prihoda NOE, ali nema razloga zašto bi tada prihod NOE u odnosu na BDP rastao.

\footnotetext{
${ }^{7}$ Ako bi obim rada bio proširen ili ako bi istraživanje uključivalo razdoblja rata i neposredno nakon rata, veličina stanovništva bila bi čimbenik kojeg bi svakako trebalo razmotriti.
} 
Što se tiče odnosa između Mi agregata i veličine NOE, opisan je kao pozitivan, jer se većina transakcija u neopaženoj ekonomiji izvršava gotovim novcem. U ovom slučaju, povećanje transakcija u neopaženoj ekonomiji više ukazuje na povećanje prihoda NOE nego na povećanje prihoda NOE u odnosu na BDP.

Stoga, ako se koriste ova dva indikatora, čini se logičnim interpretirati izlazne veličine vezane uz NOE kao veličine prihoda NOE, a ne kao veličine prihoda NOE u odnosu na BDP.

Kako se ne smatra da su izlazne vrijednosti relativne u odnosu na BDP, niti jedan od uzroka nije formiran tako da bude relativan u odnosu na BDP. 


\section{Dodatak 2.}

\section{Usporedba metoda prilagodbe}

Razlika između dviju metoda prilagodbe može se prikazati na dostupnim podacima o hrvatskom gospodarstvu, korištenim u ovom radu. Pretpostavka će biti da bi stopa rasta u prvom periodu trebala biti npr. 5\%.

\section{Tablica AI.}

Usporedba procijenjenih parametara kad su normalizirani različiti indikatori

\begin{tabular}{|l|c|c|c|c|c|c|}
\hline Varijable & $\frac{\Delta \text { Dir }_{\mathbf{t}}}{\mathbf{D i r}_{\mathbf{t}}}$ & $\frac{\Delta \text { Indir }_{\mathbf{t}}}{\text { Indir }_{\mathbf{t}}}$ & $\frac{\Delta \text { Soc }_{\mathbf{t}}}{\text { Soc }_{\mathbf{t}}}$ & $\frac{\Delta \mathbf{U R}_{\mathbf{t}}}{\mathbf{U R}_{\mathbf{t}}}$ & $\frac{\Delta \mathbf{G D P}_{\mathbf{t}}}{\mathbf{G D P}_{\mathbf{t}}}$ & $\frac{\Delta \mathbf{M 1}_{\mathbf{t}}}{\mathbf{M 1}_{\mathbf{t}}}$ \\
\hline $\begin{array}{l}\text { Stopa BDP-a } \\
\text { normalizirana }\end{array}$ & $-0.1 \mathrm{II}$ & 0.50 & -0.44 & -0.49 & I.00 & 0.58 \\
\hline $\begin{array}{l}\text { Stopa MI } \\
\text { normalizirna }\end{array}$ & -0.07 & 0.29 & -0.25 & -0.28 & 1.74 & I.00 \\
\hline
\end{tabular}

Izvor: Vlastiti izračun

Usporedba izlaznih vrijednosti modela kad su normalizirani različiti indikatori, prilagođenih zbrajanjem izgleda ovako:

\section{Slika AI.}

Prilagodba zbrajanjem

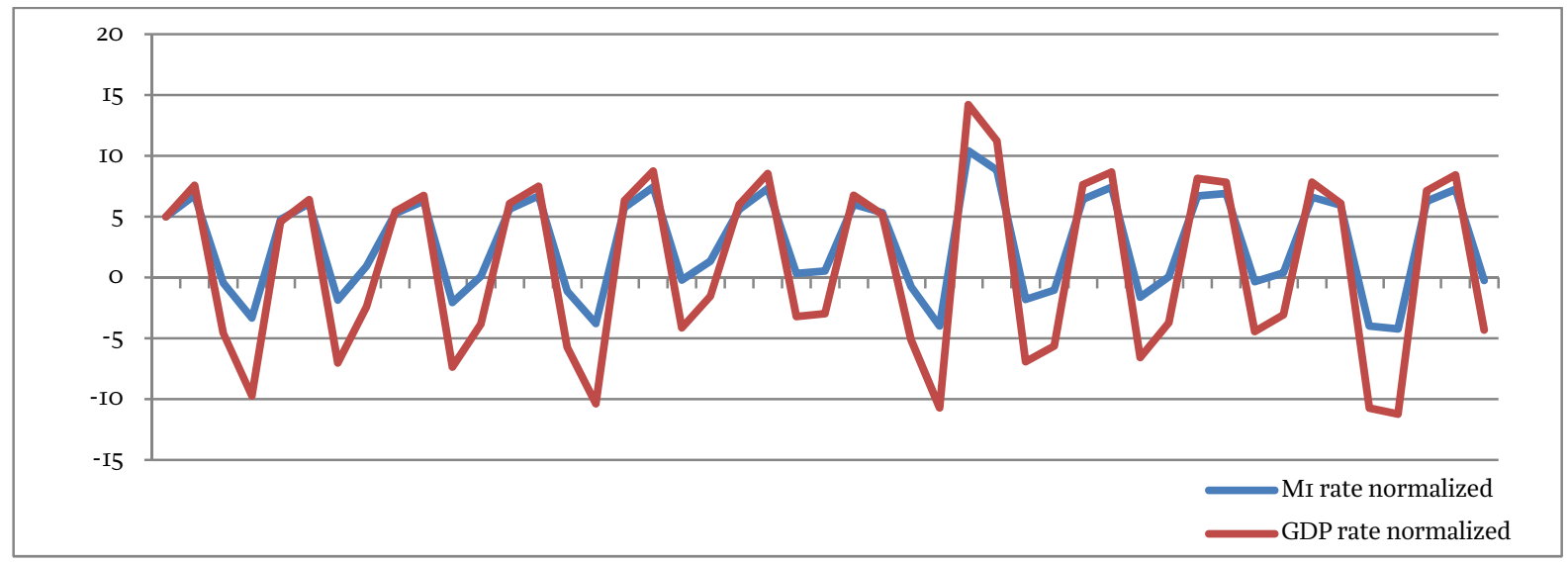

Izvor: Vlastiti izračun.

i prilagođenih množenjem: 
Slika A2.

Prilagodba mпоženjem

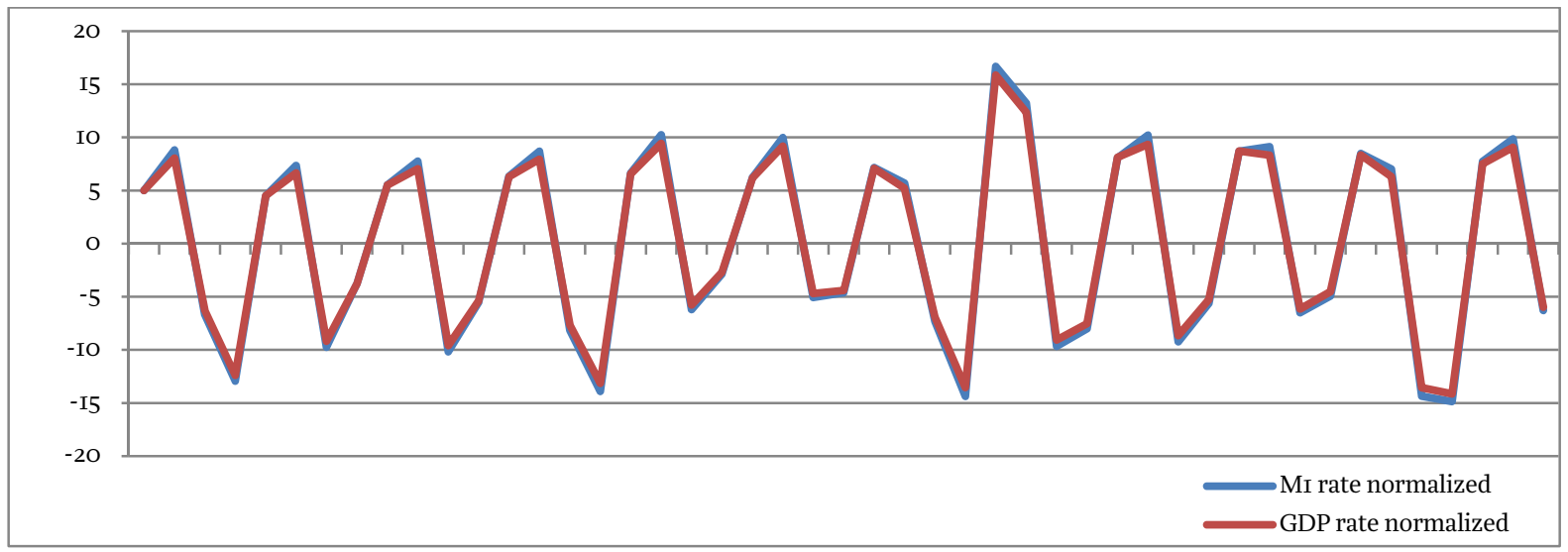

Izvor: Vlastiti izračun.

To je očekivano budući da, kao što je ranije spomenuto, MIMIC model nije u mogućnosti odrediti apsolutnu razinu svih parametara. Stoga su izlazne vrijednosti modela ustvari oblika $\widetilde{\eta}=\frac{\hat{\eta}}{\mathrm{c}}$, pri čemu $\hat{\eta}$ predstavlja stvarnu razinu (procjene) latentne varijable $\eta$, a c je nepoznat koeficijent. I to je razlog zašto je bilo kakva prilagodba uopće moguća. 


\section{Dodatak 3.}

\section{Prilagodba - izračun}

Tromjesečni prihod neopažene ekonomije označen je s NOE, godišnji prihod neopažene ekonomije izveden iz referentnih vrijednosti označen je sa $B^{*}$, a izlazne vrijednosti MIMIC-a sa $\widetilde{\eta}$. c je nepoznat koeficijent.

$$
\begin{aligned}
& \mathrm{NOE}_{1}+\mathrm{NOE}_{2}+\mathrm{NOE}_{3}+\mathrm{NOE}_{4}=\mathrm{B}_{1}^{*} \\
& \mathrm{NOE}_{5}+\mathrm{NOE}_{6}+\mathrm{NOE}_{7}+\mathrm{NOE}_{8}=\mathrm{B}_{2}^{*} \\
& \mathrm{c} \widetilde{\eta}_{1}=\frac{\mathrm{NOE}_{2}}{\mathrm{NOE}_{1}}-1, \mathrm{c} \widetilde{\eta}_{2}=\frac{\mathrm{NOE}_{3}}{\mathrm{NOE}_{2}}-1, \ldots, \mathrm{c} \widetilde{\eta}_{7}=\frac{\mathrm{NOE}_{8}}{\mathrm{NOE}_{7}}-1 \\
& \Rightarrow\left(\mathrm{c} \widetilde{\eta}_{1}+1\right) \mathrm{NOE}_{1}=\mathrm{NOE}_{2},\left(\mathrm{c} \widetilde{\eta}_{2}+1\right) \mathrm{NOE}_{2}=\mathrm{NOE}_{3}, \ldots, \\
& \left(\mathrm{c} \widetilde{\eta}_{7}+1\right) \mathrm{NOE}_{7}=\mathrm{NOE}_{8} \\
& \Rightarrow\left(\mathrm{c} \widetilde{\eta}_{1}+1\right) \mathrm{NOE}_{1}=\mathrm{NOE}_{2},\left(\mathrm{c} \widetilde{\eta}_{2}+1\right)\left(\mathrm{c} \widetilde{\eta}_{1}+1\right) \mathrm{NOE}_{1}=\mathrm{NOE}_{3}, \ldots, \\
& \left(\mathrm{c} \widetilde{\eta}_{7}+1\right) \ldots\left(\mathrm{c} \widetilde{\eta}_{2}+1\right)\left(\mathrm{c} \widetilde{\eta}_{1}+1\right) \mathrm{NOE}_{1}=\mathrm{NOE}_{8}
\end{aligned}
$$$$
\mathrm{p}_{\mathrm{i}}(\mathrm{c}):=\prod_{\mathrm{j}=1}^{\mathrm{i}}\left(\mathrm{c} \widetilde{\eta}_{\mathrm{j}}+1\right)
$$$$
\mathrm{NOE}_{1} * \mathrm{P}(\mathrm{c})=\mathrm{B}_{1}^{*}, \mathrm{P}(\mathrm{c}):=1+\mathrm{p}_{1}(\mathrm{c})+\mathrm{p}_{2}(\mathrm{c})+\mathrm{p}_{3}(\mathrm{c})
$$$$
\left.\mathrm{NOE}_{1} * \mathrm{Q}(\mathrm{c})=\mathrm{B}_{2}^{*}, \mathrm{Q}(\mathrm{c}):=\mathrm{p}_{4}(\mathrm{c})+\mathrm{p}_{5} \mathrm{c}\right)+\mathrm{p}_{6}(\mathrm{c})+\mathrm{p}_{7}(\mathrm{c})
$$

$$
\begin{aligned}
& \frac{\mathrm{B}_{1}^{*}}{\mathrm{P}(\mathrm{c})}=\frac{\mathrm{B}_{2}^{*}}{\mathrm{Q}(\mathrm{c})} \\
& \frac{\mathrm{B}_{1}^{*}}{\mathrm{~B}_{2}^{*}}=\frac{\mathrm{P}(\mathrm{c})}{\mathrm{Q}(\mathrm{c})} \\
& \frac{\mathrm{B}_{1}^{*}}{\mathrm{~B}_{2}^{*}} * \mathrm{Q}(\mathrm{c})-\mathrm{P}(\mathrm{c})=0
\end{aligned}
$$

Gornji polinom ima tri realna korijena, od kojih samo jedan dolazi u obzir kao koeficijent za prilagodbu stopa rasta. Da je bilo više korijena koji bi mogli doći u obzir, vjerojatno bi bila potrebna dodatna referentna vrijednost. 


\section{Dodatak 4.}

\section{Breuscheva kritika MIMIC pristupa}

Što se u svjetlu Breuschevih primjedbi spomenutih u točki 4.2. može reći o postupcima primijenjenim u ovom radu?

Breusch pretpostavlja da razlog za nedokumentirane transformacije podataka leži $u$ pogrešnom korištenju softvera korištenog za izračune. LISREL, kojeg spominje Breusch, barem njegove novije verzije, dozvoljavaju korisniku da odredi u kojem su obliku podaci i koji bi postupci trebali biti izvršeni nad njima. Korisnik jedino mora paziti koje opcije bira. Podaci u ovom radu nisu prolazili kroz bilo kakve značajnije transformacije, izuzev preuzimanja oblika stopa rasta.

Mjerne jedinice nisu ozbiljan čimbenik u ovom radu. Bez obzira u kojim su jedinicama izvorni podaci, one se $\mathrm{u}$ biti krate prilikom transformacije varijabli u stope rasta, nakon čega su sve ulazne varijable mjerene $u$ postocima. Jedini mogući problem $s$ jedinicama pitanje je interpretacije stopa rasta koje izlaze iz modela, no taj je eventualni problem više ekonomske prirode i nema osobite veze sa samim modelom.

Diferenciranje $\mathrm{u}$ ovom radu nije posljedica težnje za stacionarnošću, nego je nusprodukt transformacije u stope rasta. Varijable su stacionarne bez dodatnog diferenciranja, ali kointegracija između uzroka i indikatora još je prisutna. I dok oblik ulaznih varijabli nije nužno statistički gledano idealan, očito ima nekoliko poželjnih odlika, zbog čega je izabran.

Normalizacija u ovom radu izvršena je na način koji joj daje čvrsto ekonomsko zaleđe. Drugačiji predznak uistinu bi okrenuo kretanje rezultata, ali nema nikakvog objašnjenja zašto bi se ta radnja poduzela, pa to u stvari i nije opcija.

Prilagodba je stvarno ozbiljno pitanje i, kao što je prikazano u Dodatku 2, trebala bi biti izvođena množenjem. Izbor referentnih vrijednosti druga je stvar i riječ je o više ili manje proizvoljnom postupku. Zato bi MIMIC, kao što je spomenuto ranije, prvenstveno trebao biti korišten kao proširenje drugih metoda. Najveći problem s prilagođavanjem u ovom radu zahtjev je za dvije referentne vrijednosti, što uvelike usmjerava rezultirajući vremenski niz. Pa ipak, rezultat za 20oo. godinu u usporedbi s rezultatima dobivenim SNA metodom i metodom porezne evazije upućivao bi na to da je MIMIC metoda $u$ ovom slučaju dala valjano proširenje Eurostatove metode, koja je bila izvor referentnih vrijednosti.

Ne čini se da je i jedna kauzalna varijabla dominantna u ovom slučaju.

Prigovori spomenuti pod (7), (8) i (9) odnose se na pristup općenito, ne na njegove primjene. I dok su svi oni razumni i valja ih uzeti u obzir, ako ih se unaprijed uzme kao apsolutno točne, potencijalni korisnik MIMIC-a tu ne može učiniti previše, osim uopće ne koristiti ovaj pristup. To uostalom i je ono što Breusch predlaže. Pa ipak, upitnim se primjerice može smatrati je li korištenje varijabli koje si previše ne sliče loše, ili pak možda smanjuje mogućnost da su rezultati isključivo odraz jednog indikatora, a ne 
veličine NOE. Također je upitno jesu li sličnosti između neopažene ekonomije i službenog gospodarstva uzrokovane slabostima metode ili možda odražavaju prirodno stanje stvari.

Objavljen je čak i čitavi rad (Dell'Anno i Schneider, 2006) koji se isključivo bavi odgovorima na Breuscheve tvrdnje. Kako savršena metoda ne postoji, svaka metoda mora imati svoje zagovornike i kritičare, kao što je razumljivo da će različiti ljudi imati različita mišljenja o svakoj metodi. MIMIC pristup do sad je potaknuo živu raspravu, ako ne i svađu, među znanstvenicima i vjerojatno će je nastaviti poticati u doglednoj budućnosti. 


\section{Literatura}

Bajada, C., Schneider F., 2005. "The Shadow Economies of the Asia-Pacific". Pacific Economic Review, IO (3), 379-4OI.

Breusch, T., 2005. Estimating the Underground Economy using MIMIC Models [online]. Available from: [http://I29.3.20.4I/eps/em/papers/O507/0507003.pdf].

Buehn, A. and Schneider, F., 2008. "MIMIC Models, Cointegration and Error Correction: An Application to the French Shadow Economy". CESIFO Working Paper, No. 2200.

CBS. Croatian Bureau of Statistics - Released Data.

Chen, F. [et al.], 200I. "Improper Solutions in Structural Equation Models: Causes, Consequences, and Strategies". Sociological Methods and Research, 29 (4), 468-508.

Cichocki, S., 2008. „Shadow Economy and Its Relations with Tax System and State Budget in Poland 1995-2007“. Working Papers, No. 5/2008.

CNB. Statistical Survey. Zagreb: Croatian National Bank.

Dell'Anno, R. and Schneider, F., 2003. "The Shadow Economy of Italy and other OECD Countries: What do we know?". Journal of Public Finance and Public Choice, XXI (2-3), 97 - I2O

Dell'Anno, R. and Schneider, F., 2006. "Estimating the Underground Economy Using MIMIC models: A Response to T. Breusch's Critique" [online]. Working Paper No. 0607, 2006. Available from: [http://www.econ.jku.at/papers/2006/wpo6o7.pdf].

Feige, E., 1979. "How Big is the Irregular Economy”. Challenge (November-December).

Feige, E., 1990. "Defining and Estimating Underground and Informal Economies, the New Institutional Economics Approach". World Development, I8 (7), 989-1002.

Giles, M. and Tedds, D., 2002. Taxes and the Canadian Underground Economy. Toronto: Canadian Tax Association.

Gutmann, P., 1977. “The Subterranean Economy”. Financial Analyst Journal, 33 (November-December).

Jöreskog, K. and Goldberger, A., 1975. "Estimation of a Model with Multiple Indicators and Multiple Causes of a Single Latent Variable", Journal of the American Statistical Association, 70 (35I), 63I-639.

Lacko, M., 1998. „The Hidden Economies of Visegrad Countries in International Comparison: A Household Electricity Approach“ in: Hungary: Towards a Market Economy. Cambridge: Cambridge University Press, I28-I58.

Lovrinčević, Ž., Mikulić, D. and Nikšić-Paulić, B., 200I. "Pristup službene statistike procjeni neslužbenog gospodarstva”. Financijska teorija i praksa, 26 (I), 83-II6.

Madžarević-Šujster, S. and Mikulić, D., 200I. "Procjena nesluzbenog gospodarstva sustavom nacionalnih računa". Financijska teorija i praksa, 26 (I), 3I-56.

Madžarević-Šujster, S., 200I. "Procjena porezne evazije u Hrvatskoj”. Financijska teorija i praksa, 26 (I), II7-I44.

Mikulić, D., 200o. "Assessment of the Unofficial Economy in the Republic of Croatia in 1998 Using the System of National Accounts". Croatian Economic Survey, 2000-2002, 93-II7.

Ministry of Finance. Monthly Statistical Reviews and Annual Reports - various numbers. Zagreb: Ministry of Finance.

OECD, 2002. Measuring the Non-observed Economy - A Handbook. Paris: OECD.

Ott, K., 2002. "The Underground Economy in Croatia" [online]. Occasional Paper, No. I2. Available from: [http://www.ijf.hr/OPS/I2.pdf].

Schneider, F. and Enste, D., 200o. "Shadow Economies: Size, Causes and Consequences". Journal of Economic Literature, 33 (March), 77-II4.

Stapel, S., 200o. "Enlargement and Exhaustiveness: The Eurostat Pilot Project with the EU Candidate Countries". Joint Workshop on Measurement of the Non-Observed Economy. Available from: [http://www.unescap.org/stat/meet/wnoe/waisq_background2.pdf].

Tanzi, V., 1983. "The Underground Economy in the United States: Annual Estimates 1930-1980". International Monetary Fund, Staff Papers.

UN, 1993. System of National Accounts. Geneve: United Nations. 
Van Driel, O. P., 1978. "On various causes of improper solutions in maximum likelihood factor analysis”, Psychometrika, 43 (2), 225-243. 